\title{
Fatty acid ester surfactants derived from raffinose: Synthesis, characterization and structure-property profiles
}

\author{
Xuan Li ${ }^{\text {a,b,1 }}$, Yao-Wen Hai ${ }^{\text {a,b,1 }}$, Da Ma ${ }^{\text {a,b }}$, Jing Chen ${ }^{a}$, Martin G. Banwell ${ }^{\text {a,c }}$, Ping Lan ${ }^{\mathrm{a}, \mathrm{b}, *}$ \\ a Institute for Advanced and Applied Chemical Synthesis, Jinan University, Guangzhou, Guangdong 510632, China \\ ${ }^{\mathrm{b}}$ Department of Food Science and Engineering, Jinan University, Guangzhou, Guangdong 510632, China \\ ${ }^{\mathrm{c}}$ Research School of Chemistry, Institute of Advanced Studies, The Australian National University, Canberra, Australian Capital Territory 2601, Australia
}

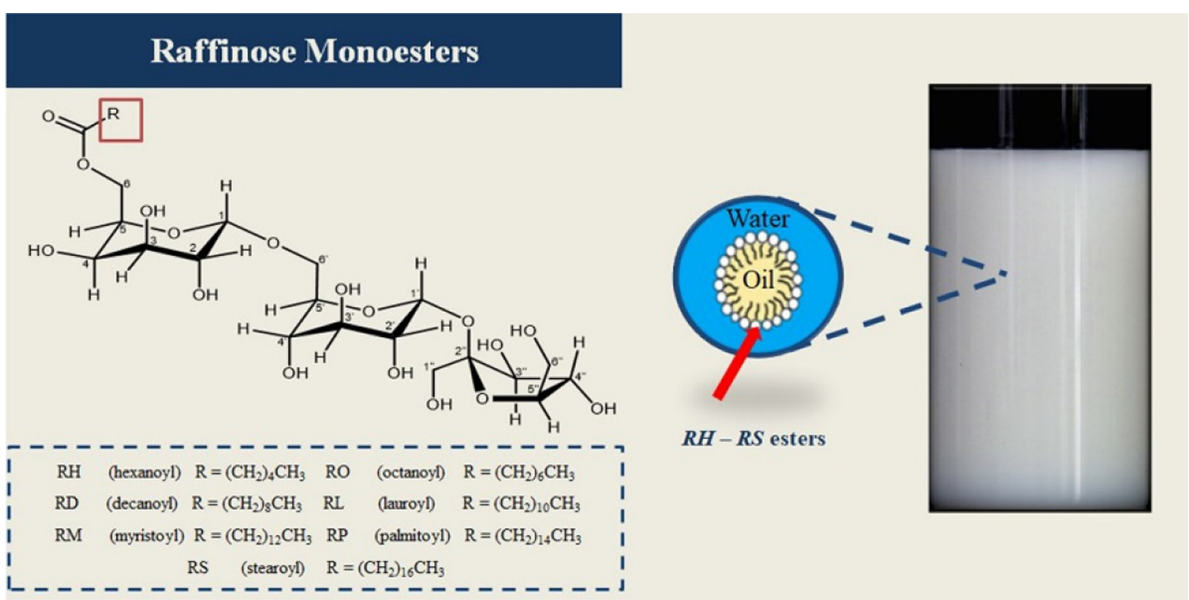

\section{A R T I C L E I N F O}

\section{Article history:}

Received 22 May 2019

Revised 18 August 2019

Accepted 19 August 2019

Available online 19 August 2019

\section{Keywords:}

Raffinose monoesters

Surface-active property

Foaming property

Emulsifying potency

Structure-property profile

Food emulsifiers

\begin{abstract}
A B S T R A C T
Hypothesis: The development of functional and nutritional surfactants for the food industry remains a subject of great interest. Herein, therefore, we report on the design and synthesis of novel trisaccharide (raffinose) monoester-based surfactants in the expectation that they would display functional properties superior to certain disaccharide-based, commercially-deployed emulsifiers and thus have potential for industrial applications.

Experiments: The title esters were prepared by enzymatic methods and their properties as surfactants evaluated through determination of their HLB values, water solubilities, CMCs, foamabilities and foaming stabilities as well as through investigation of their impacts on the stability of oil-in-water emulsions over a range of storage times and under certain other conditions.

Findings: The emulsifying properties of 6-O-acylraffinose esters are dictated, in large part, by the length of the associated alkyl chains. The results of storage and environmental stress experiments revealed that the increasing length of alkyl chains enhances the stability of the derived emulsions. All the raffinose ester-stabilized oil-in-water emulsions displayed stratification effects under strongly acidic conditions $(\mathrm{pH} \leq 4)$ or at high ionic strength $(\geq 300 \mathrm{mM})$ while possessing reasonable resistance to variations in
\end{abstract}

* Corresponding author at: Institute for Advanced and Applied Chemical Synthesis, Jinan University, Guangzhou, Guangdong 510632, China.

E-mail address: ping.lan@jnu.edu.cn (P. Lan).

1 These authors contributed equally to this work. 
temperature. As such, a number of the raffinose monoesters showed greater stability to environmental stress than their commercially-deployed and sucrose-based counterparts. The structure-property profiles established through the present study provide a definitive guide for the development of raffinose esters as novel emulsifiers, particularly in the food industry.

\section{Introduction}

Long-chain fatty acid esters of certain sugars act as non-ionic surfactants that possess characteristics suitable for broad applications in food and cosmetic formulations, as well as in the pharmaceutical and agricultural fields [1]. Such esters, which are known as bio-based surfactants, are usually produced via base-catalyzed or enzymatic transesterification reactions of sugars with the relevant fatty acid esters [2]. By controlling the degree of esterification and the nature of sugar and fatty acid residues, the specific properties of these esters, such as their hydrophilic-lipophilic balances (HLBs), can be "dialed up" over a wide range [3,4]. Since sugar esters are converted in vivo, by pancreatic lipase, into their constituent sugar and fatty acid building blocks they are regarded as readily biodegradable, non-toxic and non-irritating surfactants [5]. In addition, many such sugar esters display a variety of attractive biological activities including antimicrobial [6-8], antitumor [9], permeability-enhancing $[1,10]$ and other ones $[11,12]$. Sugar esters currently produced at commercial scale include those derived from sucrose and sorbitan (span). Certain fatty acid glucamides and alkyl polyglycosides are also of industrial significance.

Nowadays, foods are not just intended to satisfy hunger and provide nutrition but they are also sought, by consumers, for promoting a state of well-being, better health and reductions in the chances of suffering from various diseases [13]. This trend has stimulated the development of novel food additives that can be claimed to display extra health benefits. Short-chain carbohydrates (SCGs) or prebiotics are prominent in this regard being "immune" to enzymes in the human gut and sometimes, therefore, described as non-digestible oligosaccharides (NDOs) [14]. The utilization of these specific types of dietary carbohydrates as food components leads to multiple health advantages since, inter alia, they are non-carcinogenic and of low calorific value. Most significantly, they can stimulate the growth of beneficial bacteria in the colon $[14,15]$. As a consequence, the "upgrading" of certain NDOs to the corresponding fatty acid esters that can act as bio-based surfactants (emulsifiers) while maintaining their health benefits could provide highly marketable new products for the food industry.

From an industrial perspective, only a few NDOs are suitably functionalized, well-priced and sufficiently readily available to be exploited for such purposes. One is raffinose, a trisaccharide composed of galactose, glucose and fructose residues. Raffinose is widely distributed in various vegetables and can be extracted directly from beans, cabbage, brussels sprouts, broccoli and asparagus as well as from whole grains [16]. As an alpha-galactosyl derivative of sucrose, raffinose-based fatty acid esters are likely to be more water-soluble and heat stable than their sucrose counterparts. Furthermore, due to the indigestibility of raffinose, the derived esters could be consumed by diabetics [17]. Despite their potential, few fatty acid ester derivatives of raffinose have been prepared and in those instances were they have, enzymatic methods $[5,11,12,18-20]$, ultrasonically-promoted syntheses $[21,22]$ or ones involving Mitsunobu-type reaction conditions have been used [23]. Such prior work has been methodological in nature and focused on the regio-selectivities of the esterification processes. Unsurprisingly, trans-esterification usually takes place at one of the three primary hydroxyls, viz. at the galactosyl 6-OH, fructosyl $6^{\prime \prime}$ or fructosyl 1" positions.

Both the hemolytic activities and the utility of such raffinose mono-esters as detergents in the membrane biochemistry have been explored $[11,12]$, but their emulsifying properties and attendant capacities for application in the food industry remain largely undefined. So, for example, while Zhang et al. have recently prepared and characterized three raffinose-derived medium-chain fatty acid mono-esters [5], how their properties vary as a function of the length of the fatty acid residue remains unclear. Herein, therefore, we report on the first systematic evaluation of the surface-active and related properties of an homologous series of 6-O-acylraffinose esters bearing alkyl side-chains ranging from 6 to 18 carbons in length. We have investigated the interfacial properties of such synthetic trisaccharide-derived esters as well as the stabilities of certain emulsions formed using them. Their capacities to resist certain forms of environmental stress have also been established. Moreover, the effect of the hydrophobic side chain on their overall properties has been determined. Accordingly, the structure-property profile established through the current work should provide a useful guide for the development of raffinose esters as novel emulsifiers in the food industry.

\section{Materials and methods}

\subsection{Reagents}

Raffinose (99.0\%), $t$-BuOH (anhydrous), pyridine (anhydrous), $N$, $\mathrm{N}$-dimethylformamide (DMF), benzene, Span 20, Span 40, Span 60 , Span 80, Tween 20 and Tween 80 were purchased from the Energy Chemical Co., Ltd (Shanghai, China). Vinyl hexanoate (>99.0\%), vinyl $n$-octanoate $(>99.0 \%)$, vinyl decanoate $(>99.0 \%)$, vinyl laurate (>99.0\%), vinyl myristate (>99.0\%), vinyl palmitate (>96.0\%) and vinyl stearate $(>95.0 \%)$ were purchased from the Tokyo Chemical Industry Co. Ltd. (Tokyo, Japan). Novo Nordisk (Bagsværd, Denmark) provided lipozyme TLIM while the Mitsubishi-Chemical Foods Corporation was the source of the sucrose esters P-1570 and P-1670. Pure olive oil, on the other hand, was purchased from a local food store.

\subsection{General characterization protocols}

A Bruker spectrometer operating at $600 \mathrm{MHz}$ for proton and $150 \mathrm{MHz}$ for carbon nuclei was used to record one-dimensional ${ }^{1} \mathrm{H}$ and ${ }^{13} \mathrm{C}$ NMR spectra at $25^{\circ} \mathrm{C}$. HMBC spectra were recorded on the same instrument. Signals arising from the residual protioforms of the solvent were used as internal standards for calibrating ${ }^{1} \mathrm{H}$ NMR spectra. ${ }^{1} \mathrm{H}$ NMR data are recorded as follows: chemical shift $(\delta)$ [multiplicity, coupling constant(s) $J(\mathrm{~Hz})$, relative integral] where multiplicity is defined as: $\mathrm{s}=$ singlet; $\mathrm{d}=$ doublet; $\mathrm{t}=$ triplet; $\mathrm{q}=$ quartet; $\mathrm{m}=$ multiplet or combinations of the above. A singlequadrupole liquid chromatograph-mass spectrometer was used to acquire low-resolution ESI mass spectra. Eluted silica-coated thin-layer chromatographic plates (ex. Merck) were visualized using a dip followed by heating, the dip being comprised of 
potassium permanganate/potassium carbonate/5\% sodium hydroxide aqueous solution/water $(3 \mathrm{~g} / 20 \mathrm{~g} / 5 \mathrm{~mL} / 300 \mathrm{~mL})$. Flash chromatographic separations were carried out using silica gel 60 (40-63 $\mu \mathrm{m}$ ) (supplied by the Qingdao Haiyang Company, Qingdao, China) as the stationary phase and the AR-grade solvents indicated as the mobile phase.

\subsection{Synthesis of the 6-0-Acylraffinose esters}

The lipase-catalyzed syntheses of the targeted 6-O-acylraffinose esters were carried out using modifications of a published method [19]. So, lipozyme TLIM ( $1.0 \mathrm{~g}, 50 \% \mathrm{w} / \mathrm{w}$ loading) was added to a solution of $D$-raffinose $(2.0 \mathrm{~g}, 4.0 \mathrm{mmol})$ in anhydrous $t-\mathrm{BuOH} /$ pyridine $(100 \mathrm{~mL}, 11: 9 \mathrm{v} / \mathrm{v})$ that was then stirred magnetically at $60{ }^{\circ} \mathrm{C}$ and $450 \mathrm{rpm}$ for $5 \mathrm{~min}$. After this time, the relevant fatty acid vinyl ester ( 5.0 equiv., $20.0 \mathrm{mmol}$ ) was added and the resulting mixture stirred under the same conditions for a further $14 \mathrm{~h}$. The cooled reaction mixture was filtered then concentrated under reduced pressure to give a yellow oil. This oil was subjected to flash chromatography (silica, 1:1:0.6 v/v/v EtOAc/ $\mathrm{CH}_{2} \mathrm{Cl}_{2} / \mathrm{MeOH}$ elution) to give, after concentration of the appropriate fractions $\left(R_{\mathrm{f}}=0.4\right)$, the relevant $6-0$-acylraffinose ester. In each instance this was obtained as an amorphous, white solid of $>95 \%$ purity (as judged by ${ }^{1} \mathrm{H}$ NMR spectroscopic analysis).

6-O-Hexanoylraffinose (RH). Yield: $88 \% .{ }^{1} \mathrm{H}$ NMR $(600 \mathrm{MHz}$, $\left.\mathrm{CD}_{3} \mathrm{OD}\right) \delta 5.40\left(\mathrm{~d}, J=3.8 \mathrm{~Hz}, 1 \mathrm{H}, \mathrm{H}-1^{\prime}\right), 4.87(\mathrm{~m}$, partially overlapped with the signal due to residual water, $1 \mathrm{H}, \mathrm{H}-1), 4.24(\mathrm{~m}, 1 \mathrm{H}, \mathrm{H}-6 \mathrm{a})$, $4.22(\mathrm{~m}, 1 \mathrm{H}, \mathrm{H}-6 \mathrm{~b}), 4.10$ ( $\mathrm{m}, 2 \mathrm{H}, \mathrm{H}-3^{\prime \prime}$ and $\left.\mathrm{H}-4^{\prime \prime}\right), 4.05$ ( $\mathrm{m}, 2 \mathrm{H}, \mathrm{H}-5$ and $\left.\mathrm{H}^{\prime} 5^{\prime}\right), 3.87(\mathrm{dm}, J=3.0 \mathrm{~Hz}, 1 \mathrm{H}, \mathrm{H}-4), 3.83(\mathrm{dd}, J=10.5$ and $\left.6.8 \mathrm{~Hz}, 1 \mathrm{H}, \mathrm{H}-6^{\prime} \mathrm{a}\right), 3.81(\mathrm{~m}, 1 \mathrm{H}, \mathrm{H}-3), 3.76\left(\mathrm{~m}, 3 \mathrm{H}, \mathrm{H}-5^{\prime \prime}\right.$ and $\mathrm{H}-$ $\left.6^{\prime \prime}\right), 3.73(\mathrm{~m}, 1 \mathrm{H}, \mathrm{H}-2), 3.71\left(\mathrm{~m}, 1 \mathrm{H}, \mathrm{H}-3^{\prime}\right), 3.70\left(\mathrm{~m}, 1 \mathrm{H}, \mathrm{H}-6^{\prime} \mathrm{b}\right)$, 3.63 (d, $\left.J=12.3 \mathrm{~Hz}, 1 \mathrm{H}, \mathrm{H}-1^{\prime \prime} \mathrm{a}\right), 3.60$ (d, $J=12.3 \mathrm{~Hz}, 1 \mathrm{H}, \mathrm{H}-1^{\prime \prime} \mathrm{b}$ ), $3.43\left(\mathrm{dd}, J=9.8\right.$ and $3.8 \mathrm{~Hz}, 1 \mathrm{H}, \mathrm{H}-2^{\prime}$ ), 3.25 (dd, $J=10.1$ and $\left.8.9 \mathrm{~Hz}, 1 \mathrm{H}, \mathrm{H}-4^{\prime}\right), 2.34$ (t, J = 7.5 Hz, 2H, $\left.-\mathrm{CH}_{2}-\mathrm{CO}-\right), 1.63$ (m, $2 \mathrm{H}$, $\left.-\mathrm{CH}_{2}-\mathrm{CH}_{2}-\mathrm{CO}-\right), 1.33$ ( $\mathrm{m}, 4 \mathrm{H},-\mathrm{CH}_{2}-$ hexanoyl backbone), 0.92 $\left(\mathrm{t}, J=7.0 \mathrm{~Hz}, 3 \mathrm{H},-\mathrm{CH}_{3}\right) .{ }^{13} \mathrm{C}$ NMR $\left(150 \mathrm{MHz}, \mathrm{CD}_{3} \mathrm{OD}\right) \delta 175.38$ $(C=0), 105.38\left(C 2^{\prime \prime}\right), 100.56(C 1), 93.43\left(C^{\prime}\right), 83.52\left(C^{\prime \prime}\right), 79.21$ (C3"), 75.43 (C4"), 74.50 (C3'), $73.22\left(\mathrm{C5}^{\prime}\right), 73.12$ (C2'), 72.10 (C4'), 71.15 (C3), 70.98 (C4), 70.33 (C6), 69.92 (C5), 68.57 (C6'), 65.00 (C6), $64.26\left(\mathrm{C} 1^{\prime \prime}\right), 63.28\left(\mathrm{C}^{\prime \prime}\right), 35.00$ (- $\left.\mathrm{CH}_{2}-\mathrm{CO}-\right), 32.43$, 25.69, $23.41\left(-\mathrm{CH}_{2}-\mathrm{CH}_{3}\right), 14.30\left(-\mathrm{CH}_{3}\right)$. MS (ESI, +ve): $m / z 620$ $\left(\left[\mathrm{M}+\mathrm{NH}_{4}\right]^{+}, 70 \%\right), 625\left([\mathrm{M}+\mathrm{Na}]^{+}, 100\right)$.

6-O-Octanoylraffinose (RO). Yield: $80 \% .{ }^{1} \mathrm{H}$ NMR $(600 \mathrm{MHz}$, $\left.\mathrm{CD}_{3} \mathrm{OD}\right) \delta 5.40\left(\mathrm{~d}, J=3.8 \mathrm{~Hz}, 1 \mathrm{H}, \mathrm{H}-1^{\prime}\right), 4.87(\mathrm{~m}$, partially overlapped with the signal due to residual water, $1 \mathrm{H}, \mathrm{H}-1), 4.24(\mathrm{~m}, 1 \mathrm{H}, \mathrm{H}-6 \mathrm{a})$, $4.22(\mathrm{~m}, 1 \mathrm{H}, \mathrm{H}-6 \mathrm{~b}), 4.10$ ( $\mathrm{m}, 2 \mathrm{H}, \mathrm{H}-3^{\prime \prime}$ and $\left.\mathrm{H}-4^{\prime \prime}\right), 4.05$ ( $\mathrm{m}, 2 \mathrm{H}, \mathrm{H}-5$ and $\left.\mathrm{H}-5^{\prime}\right), 3.88$ (dm, $\left.J=3.0 \mathrm{~Hz}, 1 \mathrm{H}, \mathrm{H}-4\right), 3.83$ (m, 1H, H-6'a), 3.81 $(\mathrm{m}, 1 \mathrm{H}, \mathrm{H}-3), 3.76\left(\mathrm{~m}, 3 \mathrm{H}, \mathrm{H}-5^{\prime \prime}\right.$ and $\left.\mathrm{H}_{-} 6^{\prime \prime}\right), 3.73(\mathrm{~m}, 1 \mathrm{H}, \mathrm{H}-2)$, $3.71\left(\mathrm{~m}, 1 \mathrm{H}, \mathrm{H}-3^{\prime}\right), 3.70\left(\mathrm{~m}, 1 \mathrm{H}, \mathrm{H}-6^{\prime} \mathrm{b}\right), 3.63(\mathrm{~d}, J=12.3 \mathrm{~Hz}, 1 \mathrm{H}$, $\left.\mathrm{H}-1^{\prime \prime} \mathrm{a}\right), 3.60$ (d, $\left.J=12.3 \mathrm{~Hz}, 1 \mathrm{H}, \mathrm{H}-1^{\prime \prime} \mathrm{b}\right), 3.43$ (dd, $J=9.8$ and $\left.3.8 \mathrm{~Hz}, 1 \mathrm{H}, \mathrm{H}-2^{\prime}\right), 3.25$ (dd, $J=10.0$ and $\left.8.9 \mathrm{~Hz}, 1 \mathrm{H}, \mathrm{H}-4^{\prime}\right), 2.34(\mathrm{t}$, $\left.J=7.5 \mathrm{~Hz}, 2 \mathrm{H},-\mathrm{CH}_{2}-\mathrm{CO}-\right), 1.63\left(\mathrm{~m}, 2 \mathrm{H},-\mathrm{CH}_{2}-\mathrm{CH}_{2}-\mathrm{CO}-\right), 1.33$ (m, $8 \mathrm{H},-\mathrm{CH}_{2}-$ octanoyl backbone), $0.91\left(\mathrm{t}, J=7.0 \mathrm{~Hz}, 3 \mathrm{H},-\mathrm{CH}_{3}\right.$ ). ${ }^{13} \mathrm{C}$ NMR $\left(150 \mathrm{MHz}, \mathrm{CD}_{3} \mathrm{OD}\right) \delta 175.39(\mathrm{C}=\mathrm{O}), 105.38\left(\mathrm{C2}^{\prime \prime}\right), 100.55$ (C1), $93.44\left(\mathrm{C}^{\prime}\right), 83.51\left(\mathrm{C}^{\prime \prime}\right), 79.21\left(\mathrm{C}^{\prime \prime}\right), 75.43\left(\mathrm{C}^{\prime \prime}\right), 74.49$ (C3'), 73.22 (C5'), $73.11\left(\mathrm{C}^{\prime}\right), 72.10\left(\mathrm{C}^{\prime}\right), 71.14(\mathrm{C} 3), 70.97$ (C4), 70.32 (C6), 69.91 (C5), $68.56\left(\mathrm{C}^{\prime}\right), 64.97(\mathrm{C} 6), 64.26\left(\mathrm{C1}^{\prime \prime}\right), 63.28$ (C6"), 35.03 (- $\left.\underline{\mathrm{CH}}_{2}-\mathrm{CO}-\right), 32.87,30.20,30.10,26.00,23.66\left(-\mathrm{CH}_{2}-\right.$ $\left.-\mathrm{CH}_{3}\right), 14.43\left(-\mathrm{CH}_{3}\right)$. MS (ESI, +ve): $m / z 648\left(\left[\mathrm{M}+\mathrm{NH}_{4}\right]^{+}, 70 \%\right), 653$ $\left([\mathrm{M}+\mathrm{Na}]^{+}, 100\right)$.

6-O-Decanoylraffinose (RD). Yield: $72 \% .{ }^{1} \mathrm{H}$ NMR $(600 \mathrm{MHz}$, $\left.\mathrm{CD}_{3} \mathrm{OD}\right) \delta 5.40\left(\mathrm{~d}, J=3.8 \mathrm{~Hz}, 1 \mathrm{H}, \mathrm{H}-1^{\prime}\right), 4.87$ (d, partially overlapped with the signal due to residual water, $1 \mathrm{H}, \mathrm{H}-1), 4.24(\mathrm{~m}, 1 \mathrm{H}, \mathrm{H}-6 \mathrm{a})$, 4.22 (m, 1H, H-6b), 4.10 (m, 2H, H-3" and H-4"), 4.05 (m, 2H, H-5 and $\mathrm{H}^{-5^{\prime}}$ ), 3.88 (dm, $\left.J=3.0 \mathrm{~Hz}, 1 \mathrm{H}, \mathrm{H}-4\right), 3.83$ (m, $\left.1 \mathrm{H}, \mathrm{H}-6^{\prime} \mathrm{a}\right), 3.81$ $(\mathrm{m}, 1 \mathrm{H}, \mathrm{H}-3), 3.76\left(\mathrm{~m}, 3 \mathrm{H}, \mathrm{H}-5^{\prime \prime}\right.$ and $\left.\mathrm{H}-6^{\prime \prime}\right), 3.73(\mathrm{~m}, 1 \mathrm{H}, \mathrm{H}-2)$, $3.71\left(\mathrm{~m}, 1 \mathrm{H}, \mathrm{H}-3^{\prime}\right), 3.70\left(\mathrm{~m}, 1 \mathrm{H}, \mathrm{H}-6^{\prime} \mathrm{b}\right), 3.63(\mathrm{~d}, J=12.3 \mathrm{~Hz}, 1 \mathrm{H}$, $\left.\mathrm{H}-1^{\prime \prime} \mathrm{a}\right), 3.60$ (d, $\left.J=12.3 \mathrm{~Hz}, 1 \mathrm{H}, \mathrm{H}-1^{\prime \prime} \mathrm{b}\right), 3.43$ (dd, $J=9.8$ and $\left.3.8 \mathrm{~Hz}, 1 \mathrm{H}, \mathrm{H}-2^{\prime}\right), 3.25\left(\mathrm{dd}, J=10.1\right.$ and $\left.8.9 \mathrm{~Hz}, 1 \mathrm{H}, \mathrm{H}-4^{\prime}\right), 2.34(\mathrm{t}$, $\left.J=7.5 \mathrm{~Hz}, 2 \mathrm{H},-\underline{\mathrm{CH}}_{2}-\mathrm{CO}-\right), 1.63\left(\mathrm{~m}, 2 \mathrm{H},-\underline{\mathrm{C}}_{2}-\mathrm{CH}_{2}-\mathrm{CO}-\right), 1.33$ (m, $12 \mathrm{H},-\mathrm{CH}_{2}-$ decanoyl backbone), $0.91(\mathrm{t}, J=7.0 \mathrm{~Hz}, 3 \mathrm{H}$, $\left.-\mathrm{CH}_{3}\right) .{ }^{13} \mathrm{C}$ NMR $\left(150 \mathrm{MHz}, \mathrm{CD}_{3} \mathrm{OD}\right) \delta 175.39(\mathrm{C}=\mathrm{O}), 105.37\left(\mathrm{C}^{\prime \prime}\right)$, $100.54(\mathrm{C} 1), 93.44\left(\mathrm{C}^{\prime}\right), 83.51\left(\mathrm{C}^{\prime \prime}\right), 79.21\left(\mathrm{C}^{\prime \prime}\right), 75.43\left(\mathrm{C} 4^{\prime \prime}\right)$, $74.49\left(\mathrm{C} 3^{\prime}\right), 73.22\left(\mathrm{C}^{\prime}\right), 73.11\left(\mathrm{C}^{\prime}\right), 72.11\left(\mathrm{C} 4^{\prime}\right), 71.14(\mathrm{C} 3), 70.96$ (C4), 70.32 (C6), 69.90 (C5), 68.56 (C6'), 64.97 (C6), $64.26\left(\mathrm{C1}^{\prime \prime}\right)$, 63.27 (C6"), 35.03 (- $\left.\mathrm{CH}_{2}-\mathrm{CO}-\right), 33.05,30.60,30.44,30.40$, 30.24, 26.00, $23.73\left(-\mathrm{CH}_{2}-\mathrm{CH}_{3}\right), 14.44\left(-\mathrm{CH}_{3}\right) . \mathrm{MS}$ (ESI, +ve): $m /$ $z 676\left(\left[\mathrm{M}+\mathrm{NH}_{4}\right]^{+}, 50 \%\right), 681\left([\mathrm{M}+\mathrm{Na}]^{+}, 100\right)$.

6-O-Lauroylraffinose (RL). Yield: $70 \% .{ }^{1} \mathrm{H}$ NMR $\left(600 \mathrm{MHz}, \mathrm{CD}_{3^{-}}\right.$ OD) $\delta 5.40\left(\mathrm{~d}, J=3.8 \mathrm{~Hz}, 1 \mathrm{H}, \mathrm{H}-1^{\prime}\right), 4.87(\mathrm{~m}$, partially overlapped with the signal due to residual water, $1 \mathrm{H}, \mathrm{H}-1), 4.24(\mathrm{~m}, 1 \mathrm{H}, \mathrm{H}-$ 6a), $4.22(\mathrm{~m}, 1 \mathrm{H}, \mathrm{H}-6 \mathrm{~b}), 4.10\left(\mathrm{~m}, 2 \mathrm{H}, \mathrm{H}-3^{\prime \prime}\right.$ and $\left.\mathrm{H}-4^{\prime \prime}\right), 4.05(\mathrm{~m}, 2 \mathrm{H}$, H-5 and H-5'), 3.88 (dm, $J=3.0 \mathrm{~Hz}, 1 \mathrm{H}, \mathrm{H}-4), 3.83$ (m, 1H, H-6'a), $3.81(\mathrm{~m}, 1 \mathrm{H}, \mathrm{H}-3), 3.76\left(\mathrm{~m}, 3 \mathrm{H}, \mathrm{H}-5^{\prime \prime}\right.$ and $\left.\mathrm{H}-6^{\prime \prime}\right), 3.73(\mathrm{~m}, 1 \mathrm{H}, \mathrm{H}-$ 2), $3.71\left(\mathrm{~m}, 1 \mathrm{H}, \mathrm{H}-3^{\prime}\right), 3.70\left(\mathrm{~m}, 1 \mathrm{H}, \mathrm{H}-6^{\prime} \mathrm{b}\right), 3.63(\mathrm{~d}, J=12.3 \mathrm{~Hz}$, $1 \mathrm{H}, \mathrm{H}-1^{\prime \prime} \mathrm{a}$ ), 3.60 (d, $J=12.3 \mathrm{~Hz}, 1 \mathrm{H}, \mathrm{H}-1^{\prime \prime} \mathrm{b}$ ), 3.43 (dd, $J=9.8$ and $\left.3.8 \mathrm{~Hz}, 1 \mathrm{H}, \mathrm{H}-2^{\prime}\right), 3.25\left(\mathrm{dd}, J=10.1\right.$ and $\left.8.9 \mathrm{~Hz}, 1 \mathrm{H}, \mathrm{H}-4^{\prime}\right), 2.34(\mathrm{t}$, $\left.J=7.5 \mathrm{~Hz}, 2 \mathrm{H},-\mathrm{CH}_{2}-\mathrm{CO}-\right), 1.63\left(\mathrm{~m}, 2 \mathrm{H},-\mathrm{CH}_{2}-\mathrm{CH}_{2}-\mathrm{CO}-\right), 1.33$ (m, $16 \mathrm{H},-\mathrm{CH}_{2}-$ lauroyl backbone), $0.91\left(\mathrm{t}, J=7.0 \mathrm{~Hz}, 3 \mathrm{H},-\mathrm{CH}_{3}\right.$ ). ${ }^{13} \mathrm{C}$ NMR (150 MHz, CD $\left.{ }_{3} \mathrm{OD}\right) \delta 175.40(\mathrm{C}=\mathrm{O}), 105.38\left(\mathrm{C2}^{\prime \prime}\right), 100.54$ (C1), $93.44\left(\mathrm{C}^{\prime}\right), 83.52\left(\mathrm{C}^{\prime \prime}\right), 79.22\left(\mathrm{C}^{\prime \prime}\right), 75.43\left(\mathrm{C}^{\prime \prime}\right), 74.50$ (C3'), $73.22\left(\mathrm{C}^{\prime}\right), 73.12\left(\mathrm{C}^{\prime}\right), 72.11\left(\mathrm{C}^{\prime}\right), 71.15(\mathrm{C} 3), 70.97(\mathrm{C} 4)$, 70.33 (C6), 69.90 (C5), 68.56 (C6'), 64.97 (C6), $64.26\left(\mathrm{C1}^{\prime \prime}\right), 63.27$ $\left(\mathrm{C}^{\prime \prime}\right), 35.03$ (- $\left.\mathrm{CH}_{2}-\mathrm{CO}-\right), 33.07,30.75,30.74,30.64,30.47$, $30.45,30.25,26.00,23.74\left(-\mathrm{CH}_{2}-\mathrm{CH}_{3}\right), 14.44\left(-\mathrm{CH}_{3}\right) . \mathrm{MS}$ (ESI, +ve): $m / z 704\left(\left[\mathrm{M}+\mathrm{NH}_{4}\right]^{+}, 50 \%\right), 709\left([\mathrm{M}+\mathrm{Na}]^{+}, 100\right)$.

6-O-Myristoylraffinose (RM). Yield: $58 \% .{ }^{1} \mathrm{H}$ NMR $(600 \mathrm{MHz}$, $\left.\mathrm{CD}_{3} \mathrm{OD}\right) \delta 5.40\left(\mathrm{~d}, J=3.8 \mathrm{~Hz}, 1 \mathrm{H}, \mathrm{H}-1^{\prime}\right), 4.87$ (m, partially overlapped with the signal due to residual water, $1 \mathrm{H}, \mathrm{H}-1), 4.24(\mathrm{~m}, 1 \mathrm{H}, \mathrm{H}-6 \mathrm{a})$, $4.22(\mathrm{~m}, 1 \mathrm{H}, \mathrm{H}-6 \mathrm{~b}), 4.10\left(\mathrm{~m}, 2 \mathrm{H}, \mathrm{H}-3^{\prime \prime}\right.$ and $\left.\mathrm{H}-4^{\prime \prime}\right), 4.05(\mathrm{~m}, 2 \mathrm{H}, \mathrm{H}-5$ \left. and ${\mathrm{H}-5^{\prime}}^{\prime}\right), 3.88(\mathrm{dm}, J=3.0 \mathrm{~Hz}, 1 \mathrm{H}, \mathrm{H}-4), 3.83\left(\mathrm{~m}, 1 \mathrm{H}, \mathrm{H}-6^{\prime} \mathrm{a}\right), 3.81$ (m, $1 \mathrm{H}, \mathrm{H}-3), 3.76\left(\mathrm{~m}, 3 \mathrm{H}, \mathrm{H}-5^{\prime \prime}\right.$ and $\left.\mathrm{H}-6^{\prime \prime}\right), 3.73(\mathrm{~m}, 1 \mathrm{H}, \mathrm{H}-2)$, $3.71\left(\mathrm{~m}, 1 \mathrm{H}, \mathrm{H}-3^{\prime}\right), 3.70\left(\mathrm{~m}, 1 \mathrm{H}, \mathrm{H}-6^{\prime} \mathrm{b}\right), 3.63(\mathrm{~d}, J=12.3 \mathrm{~Hz}, 1 \mathrm{H}$, H-1"a), 3.60 (d, $J=12.3 \mathrm{~Hz}, 1 \mathrm{H}, \mathrm{H}-1^{\prime \prime} \mathrm{b}$ ), 3.43 (dd, $J=9.8$ and $3.8 \mathrm{~Hz}, 1 \mathrm{H}, \mathrm{H}-2^{\prime}$ ), 3.25 (dd, $J=10.1$ and $\left.8.9 \mathrm{~Hz}, 1 \mathrm{H}, \mathrm{H}-4^{\prime}\right), 2.34(\mathrm{t}$, $\left.J=7.5 \mathrm{~Hz}, 2 \mathrm{H},-\mathrm{CH}_{2}-\mathrm{CO}-\right), 1.63\left(\mathrm{~m}, 2 \mathrm{H},-\mathrm{CH}_{2}-\mathrm{CH}_{2}-\mathrm{CO}-\right), 1.33$ (m, 20H, $-\mathrm{CH}_{2}-$ myristoyl backbone), $0.91(\mathrm{t}, J=7.0 \mathrm{~Hz}, 3 \mathrm{H}$, $\left.-\mathrm{CH}_{3}\right) .{ }^{13} \mathrm{C}$ NMR $\left(150 \mathrm{MHz}, \mathrm{CD}_{3} \mathrm{OD}\right) \delta 175.40(\mathrm{C}=\mathrm{O}), 105.38\left(\mathrm{C2}^{\prime \prime}\right)$, $100.53(\mathrm{C} 1), 93.44\left(\mathrm{C}^{\prime}\right), 83.51\left(\mathrm{C}^{\prime \prime}\right), 79.23\left(\mathrm{C}^{\prime \prime}\right), 75.43\left(\mathrm{C} 4^{\prime \prime}\right)$, $74.49\left(\mathrm{C3}^{\prime}\right), 73.21\left(\mathrm{C}^{\prime}\right), 73.11\left(\mathrm{C} 2^{\prime}\right), 72.11\left(\mathrm{C} 4^{\prime}\right), 71.14(\mathrm{C} 3), 70.96$ (C4), 70.32 (C6), 69.90 (C5), 68.55 (C6'), 64.96 (C6), $64.26\left(\mathrm{C1}^{\prime \prime}\right)$, 63.27 (C6"), 35.03 (- $\left.\mathrm{CH}_{2}-\mathrm{CO}-\right), 33.07,30.80,30.79,30.76$, $30.74,30.65,30.48,30.45,30.26,26.00,23.73\left(-\mathrm{CH}_{2}-\mathrm{CH}_{3}\right), 14.44$ $\left(-\mathrm{CH}_{3}\right) . \mathrm{MS}(\mathrm{ESI},+\mathrm{ve}): \mathrm{m} / \mathrm{z} 732\left(\left[\mathrm{M}+\mathrm{NH}_{4}\right]^{+}, 50 \%\right), 737\left([\mathrm{M}+\mathrm{Na}]^{+}\right.$, 100).

6-0-Palmitoylraffinose (RP). Yield: $49 \% .{ }^{1} \mathrm{H}$ NMR $(600 \mathrm{MHz}$, $\left.\mathrm{CD}_{3} \mathrm{OD}\right) \delta 5.40\left(\mathrm{~d}, J=3.8 \mathrm{~Hz}, 1 \mathrm{H}, \mathrm{H}-1^{\prime}\right), 4.87$ (m, partially overlapped with the signal due to residual water, $1 \mathrm{H}, \mathrm{H}-1), 4.24(\mathrm{~m}, 1 \mathrm{H}, \mathrm{H}-6 \mathrm{a})$, $4.22(\mathrm{~m}, 1 \mathrm{H}, \mathrm{H}-6 \mathrm{~b}), 4.10$ (m, 2H, H-3" and $\left.\mathrm{H}-4^{\prime \prime}\right), 4.05$ (m, 2H, H-5 and $\left.\mathrm{H}^{\prime} 5^{\prime}\right), 3.88$ (dm, $\left.J=3.0 \mathrm{~Hz}, 1 \mathrm{H}, \mathrm{H}-4\right), 3.83$ (m, 1H, H-6'a), 3.81 $(\mathrm{m}, 1 \mathrm{H}, \mathrm{H}-3), 3.76\left(\mathrm{~m}, 3 \mathrm{H}, \mathrm{H}-5^{\prime \prime}\right.$ and $\left.\mathrm{H}-6^{\prime \prime}\right), 3.73(\mathrm{~m}, 1 \mathrm{H}, \mathrm{H}-2)$, $3.71\left(\mathrm{~m}, 1 \mathrm{H}, \mathrm{H}-3^{\prime}\right), 3.70\left(\mathrm{~m}, 1 \mathrm{H}, \mathrm{H}-6^{\prime} \mathrm{b}\right), 3.63(\mathrm{~d}, J=12.3 \mathrm{~Hz}, 1 \mathrm{H}$, H-1"a), 3.60 (d, $J=12.3 \mathrm{~Hz}, 1 \mathrm{H}, \mathrm{H}-1^{\prime \prime} \mathrm{b}$ ), 3.43 (dd, $J=9.8$ and $3.8 \mathrm{~Hz}, 1 \mathrm{H}, \mathrm{H}-2^{\prime}$ ), 3.25 (dd, $J=10.1$ and $\left.8.9 \mathrm{~Hz}, 1 \mathrm{H}, \mathrm{H}-4^{\prime}\right), 2.34$ (t, $\left.J=7.5 \mathrm{~Hz}, 2 \mathrm{H},-\mathrm{CH}_{2}-\mathrm{CO}-\right), 1.63\left(\mathrm{~m}, 2 \mathrm{H},-\mathrm{CH}_{2}-\mathrm{CH}_{2}-\mathrm{CO}-\right), 1.33$ (m, 24H, $-\mathrm{CH}_{2}-$ palmitoyl backbone), $0.91(\mathrm{t}, J=7.0 \mathrm{~Hz}, 3 \mathrm{H}$, $\left.-\mathrm{CH}_{3}\right) .{ }^{13} \mathrm{C}$ NMR $\left(150 \mathrm{MHz}, \mathrm{CD}_{3} \mathrm{OD}\right) \delta 175.39(\mathrm{C}=\mathrm{O}), 105.37\left(\mathrm{C}^{\prime \prime}\right)$, 100.55 (C1), $93.44\left(\mathrm{C}^{\prime}\right), 83.52\left(\mathrm{C}^{\prime \prime}\right), 79.22\left(\mathrm{C} 3^{\prime \prime}\right), 75.42\left(\mathrm{C} 4^{\prime \prime}\right)$, 
$74.49\left(\mathrm{C}^{\prime}\right), 73.22\left(\mathrm{C}^{\prime}\right), 73.12\left(\mathrm{C}^{\prime}\right), 72.12\left(\mathrm{C}^{\prime}\right), 71.15(\mathrm{C} 3), 70.96$ (C4), 70.33 (C6), 69.90 (C5), $68.57\left(\mathrm{C6}^{\prime}\right), 64.96$ (C6), 64.27 (C1"), 63.26 (C6"), 35.03 (- $\left.\mathrm{CH}_{2}-\mathrm{CO}-\right), 33.07,30.81,30.80$ (x3), 30.76, $30.74,30.65,30.48,30.45,30.26,26.01,23.73\left(-\mathrm{CH}_{2}-\mathrm{CH}_{3}\right), 14.44$ $\left(-\mathrm{CH}_{3}\right)$. MS (ESI, +ve): $m / z 760\left(\left[\mathrm{M}+\mathrm{NH}_{4}\right]^{+}, 50 \%\right), 765\left([\mathrm{M}+\mathrm{Na}]^{+}\right.$, 100).

6-O-Stearoylraffinose (RS). Yield: $47 \% .{ }^{1} \mathrm{H}$ NMR $(600 \mathrm{MHz}$, $\left.\mathrm{CD}_{3} \mathrm{OD}\right) \delta 5.40\left(\mathrm{~d}, J=3.8 \mathrm{~Hz}, 1 \mathrm{H}, \mathrm{H}-1^{\prime}\right), 4.87(\mathrm{~m}$, partially overlapped with the signal due to residual water, $1 \mathrm{H}, \mathrm{H}-1), 4.24(\mathrm{~m}, 1 \mathrm{H}, \mathrm{H}-6 \mathrm{a})$, $4.22(\mathrm{~m}, 1 \mathrm{H}, \mathrm{H}-6 \mathrm{~b}), 4.10\left(\mathrm{~m}, 2 \mathrm{H}, \mathrm{H}-3^{\prime \prime}\right.$ and $\left.\mathrm{H}-4^{\prime \prime}\right), 4.05$ ( $\mathrm{m}, 2 \mathrm{H}, \mathrm{H}-5$ and $\left.\mathrm{H}-5^{\prime}\right), 3.88(\mathrm{dm}, J=3.0 \mathrm{~Hz}, 1 \mathrm{H}, \mathrm{H}-4), 3.83$ (m, $\left.1 \mathrm{H}, \mathrm{H}-6^{\prime} \mathrm{a}\right), 3.81$ $(\mathrm{m}, 1 \mathrm{H}, \mathrm{H}-3), 3.76\left(\mathrm{~m}, 3 \mathrm{H}, \mathrm{H}-5^{\prime \prime}\right.$ and $\left.\mathrm{H}-6^{\prime \prime}\right), 3.73(\mathrm{~m}, 1 \mathrm{H}, \mathrm{H}-2)$, $3.71\left(\mathrm{~m}, 1 \mathrm{H}, \mathrm{H}-3^{\prime}\right), 3.70\left(\mathrm{~m}, 1 \mathrm{H}, \mathrm{H}-6^{\prime} \mathrm{b}\right), 3.63(\mathrm{~d}, J=12.3 \mathrm{~Hz}, 1 \mathrm{H}$, $\left.\mathrm{H}-1^{\prime \prime} \mathrm{a}\right), 3.60$ (d, $\left.J=12.3 \mathrm{~Hz}, 1 \mathrm{H}, \mathrm{H}-1^{\prime \prime} \mathrm{b}\right), 3.43$ (dd, $J=9.8$ and $\left.3.8 \mathrm{~Hz}, 1 \mathrm{H}, \mathrm{H}-2^{\prime}\right), 3.25\left(\mathrm{dd}, J=10.1\right.$ and $\left.8.9 \mathrm{~Hz}, 1 \mathrm{H}, \mathrm{H}-4^{\prime}\right), 2.34$ (t, $\left.J=7.5 \mathrm{~Hz}, 2 \mathrm{H},-\mathrm{CH}_{2}-\mathrm{CO}-\right), 1.63\left(\mathrm{~m}, 2 \mathrm{H},-\mathrm{CH}_{2}-\mathrm{CH}_{2}-\mathrm{CO}-\right)$, $1.33\left(\mathrm{~m}, 28 \mathrm{H},-\mathrm{CH}_{2}-\right.$ stearoyl backbone), $0.91(\mathrm{t}, J=7.0 \mathrm{~Hz}, 3 \mathrm{H}$, $\left.-\mathrm{CH}_{3}\right) .{ }^{13} \mathrm{C}$ NMR $\left(150 \mathrm{MHz}, \mathrm{CD}_{3} \mathrm{OD}\right) \delta 175.39(\mathrm{C}=\mathrm{O}), 105.38\left(\mathrm{C}^{\prime \prime}\right)$, 100.53 (C1), $93.44\left(\mathrm{C}^{\prime}\right), 83.52\left(\mathrm{C}^{\prime \prime}\right), 79.24\left(\mathrm{C} 3^{\prime \prime}\right), 75.43\left(\mathrm{C} 4^{\prime \prime}\right)$, $74.49\left(\mathrm{C}^{\prime}\right), 73.21\left(\mathrm{C}^{\prime}\right), 73.12\left(\mathrm{C2}^{\prime}\right), 72.11\left(\mathrm{C}^{\prime}\right), 71.14(\mathrm{C} 3), 70.96$ (C4), 70.32 (C6), 69.90 (C5), 68.55 (C6'), 64.96 (C6), 64.27 (C1"), $63.27\left(\mathrm{C6}^{\prime \prime}\right), 35.03$ (- $\left.\mathrm{CH}_{2}-\mathrm{CO}-\right), 33.07,30.79$ (x6), 30.76, 30.75, $30.65, \quad 30.4730 .46 \quad 30.26,26.01,23.74\left(-\mathrm{CH}_{2}-\mathrm{CH}_{3}\right), 14.44$ $\left(-\mathrm{CH}_{3}\right)$. MS (ESI, +ve): $m / z 788\left(\left[\mathrm{M}+\mathrm{NH}_{4}\right]^{+}, 20 \%\right), 793\left([\mathrm{M}+\mathrm{Na}]^{+}\right.$, 100).

2.4. Protocols used for determining the emulsifying properties of the 6O-acylraffinose esters

In order to understand their emulsifying properties, the hydrophilic-lipophilic balance (HLB) value, water solubility, critical micelle concentration (CMC), foamability and foaming stability of each ester was determined. The methods used for such purposes are detailed immediately below.

\subsubsection{Hydrophilic-Lipophilic balance (HLB)}

The HLB values of esters RH to RS, obtained as detailed above, were determined experimentally using the water number method [24]. Thus, a solution of each ester (200 $\mathrm{mg}$ in $5 \mathrm{~mL}$ of a $100: 1 \mathrm{v} / \mathrm{v}$ mixture of DMF/benzene) maintained at $25^{\circ} \mathrm{C}$ was slowly treated with distilled water until a permanent turbidity was observed then a plot of HLB vs consumed water number was established using emulsifiers with known HLB values. These included, for calibration purposes, Span $80(\mathrm{HLB}=4.3)$, Span $60(\mathrm{HLB}=4.8)$, Span 40 $(\mathrm{HLB}=6.7)$, Span $20(\mathrm{HLB}=8.6)$, Tween $80(\mathrm{HLB}=15.6)$ and Tween 20 (HLB = 16.7). All results were reproducible to within 0.5 units of HLB. The HLB values of esters RH to RS, as well as those of the commercial sucrose palmitoyl esters P-1570 and P-1670, were then read from this plot. All the experiments were performed in triplicate. The theoretical HLB values were calculated using Griffin's method [6].

\subsubsection{Water solubility}

A saturated aqueous solution of each raffinose mono-ester in distilled water maintained at $25 \pm 1^{\circ} \mathrm{C}$ was prepared. An ovendried $25 \mathrm{~mL}$ round-bottom flask was weighed $\left(W_{1}\right)$ then ca. $1 \mathrm{~mL}$ of the saturated solution transferred into the flask and the total weight recorded $\left(W_{2}\right)$. The resulting solution was concentrated under reduced pressure then cooled to $25 \pm 1{ }^{\circ} \mathrm{C}$ and the weight $\left(W_{3}\right)$ recorded at this temperature. The solubility of each sample was calculated using the following equations:

The weight of the soluble sample (mg) $W_{s}=W_{3}-W_{1}$ The weight of the distilled water $(\mathrm{g}) W_{w}=W_{2}-W_{3}$ Water solubility $(\mathrm{mg} / \mathrm{mL})=W_{S} / W_{W}$

\subsubsection{Critical micelle concentrations (CMCs)}

The CMCs of compounds RH to RS as well as those of the sucrose esters P-1670 and P-1570 were determined using the Wilhelmy plate method [25]. So, aqueous solutions of varying concentrations of the esters were kept at $28^{\circ} \mathrm{C}$ and the equilibrium surface tension of each measured using a Krüss tensiometer (Processor Tensiometer K-12, Hamburg, Germany). An equilibration time of at least one hour was allowed before surface tension measurements were carried out. By plotting the break in the surface tension value versus $\log _{10}$ concentration, the CMC of each sample was calculated. This is expressed in $\mu \mathrm{M}$ where $\gamma_{\mathrm{CMC}}$ represents the surface tension corresponding to the CMC.

\subsubsection{Foamability and foaming stability}

Samples of the esters RH to RS as well the controls P-1570, $\mathrm{P}-1670$ and Tween 20 (20 mL of each as $0.2 \%$ and $0.5 \% \mathrm{w} / \mathrm{w}$ aqueous dispersions) were each placed in a centrifuge tube $(100 \mathrm{~mL})$ and the height of the solution $\left(H_{0}\right)$ measured. Each sample was placed in a blender operating at $10,000 \mathrm{rpm}$ for $1 \mathrm{~min}$ and the resulting foam height $\left(H_{2}\right)$ as well as the total height $\left(H_{1}\right)$ for each determined immediately thereafter. The new foam heights $\left(\mathrm{H}_{3}\right)$ were recorded after the samples had been allowed to stand for $10,20,3040,50$ and 60 min while the associated foaming stabilities and foamabilities were calculated using the following simple equations [5]:

Foaming stability $(\%)=\mathrm{H}_{3} / \mathrm{H}_{2} \times 100 \%$

Foamability $(\%)=\left(H_{1}-H_{0}\right) / H_{0} \times 100 \%$

\subsection{Emulsion preparation}

$60.0 \mathrm{~g}$ of $0.3 \% \mathrm{w} / \mathrm{w}$ aqueous solutions of esters RH to RS as well as controls P-1670 and Tween 20 were each placed in separate $100 \mathrm{~mL}$ centrifuge tubes to which was added $3.0 \mathrm{~g}$ of Olivia ${ }^{\mathrm{TM}}$ virgin olive oil. In the cases of RS and P-1670, $t-\mathrm{BuOH}(3 \%)$ was added as a solubilizer. The resulting mixtures were homogenized for $2 \mathrm{~min}$ at $10,000 \mathrm{rpm}$ in a blender. The coarse emulsion was then passed through a high-pressure homogenizer (AH-BASIC 30, ATS Engineering Limited, Ontario, Canada) for five cycles under $900 \mathrm{KPa}$ so as to produce the final emulsion.

\subsection{Determination of droplet size and droplet size distributions}

The characteristics of the droplets in the oil-in-water emulsions produced using esters RH to RS as well as controls P-1670 and Tween 20 were measured by static light scattering techniques using a Mastersizer 2000 (Malvern Instruments, Worcestershire, UK). $100 \mu \mathrm{L}$ of each sample was diluted to $1000 \mu \mathrm{L}$ before testing. The droplet size distributions after $1,2,3,4,5,7,9,11,13$ days were measured at $25^{\circ} \mathrm{C}$ while the appearance of each emulsion was documented using a digital camera.

\subsection{Stability of the $\boldsymbol{R L}$ to $\boldsymbol{R S}$ - stabilized emulsions under environmental stress}

The impacts of $\mathrm{pH}$, temperature and ionic strength on the stability of the emulsions were evaluated on the basis of their droplet size distributions and appearance. The methods employed are as follows:

$\mathrm{pH}$ : The oil-in-water emulsions were prepared by mixing a $95 \%$ aqueous solution of the test sample $(0.3 \% \mathrm{w} / \mathrm{w})$ with $5 \%$ olive oil at $\mathrm{pH}$ values of $4,6,8,10$. The pressures used in producing the primary and second forms of the homogenates were 90 psi and 900 psi, respectively. The final emulsions were cooled to ambient temperatures then analyzed after storage for 1, 24 and $48 \mathrm{~h}$. 
Temperature: $20 \mathrm{~mL}$ aliquots of the emulsions stabilized by $\mathbf{R} \mathbf{L}$ to $\mathbf{R S}$ and P-1670 were placed in glass tubes then heated in a water bath at 50,70 , and $90^{\circ} \mathrm{C}$ for $30 \mathrm{~min}$. The resulting emulsion was then cooled and stored at $4{ }^{\circ} \mathrm{C}$ for $24 \mathrm{~h}$ (in order to inhibit microbial growth) prior to analysis.

Ionic strength: $10 \mathrm{~g}$ samples of each of the $\mathbf{R L}$ to $\mathbf{R S}$-stabilized emulsions were placed in beaker and treated with $0.4 \mathrm{~mL}$ of aqueous $\mathrm{NaCl}$ solutions to afford emulsions of varying concentrations $(150,300,450,600 \mathrm{mM})$ and ionic strengths. These samples were analyzed immediately after formation.

\subsection{Statistical analyses}

Results are presented as mean values \pm standard deviation (SD) and experiments were performed in triplicate. In order to identify any significant differences, statistical analyses were performed using SPSS software (SPSS, Inc., Chicago, IL). All values were assessed by one-way analysis of variance (ANOVA) in conjunction with Duncan's new multiple-range test (MRT). A difference was considered significant when $P<0.05$.

\section{Results and discussion}

3.1. Synthesis and structural characterization of the 6-O-Acylraffinose esters

The rates and regioselectivities associated with the enzymatic acylation of raffinose have been studied extensively [3]. A range of enzymes, most notably immobilized Thermonmyces lanuginosus lipase (viz. lipozyme TLIM) [5], the metalloprotease thermolysin [19] and subtilisin [20] have been employed for this purpose with various long-chain fatty acids or their derivatives being used as the acyl donors. In the current work, screening a range of solvent systems established that $t$ - $\mathrm{BuOH} /$ pyridine $(11: 9 \mathrm{v} / \mathrm{v})$ provided the best medium while a survey of the various enzymes available to us indicated that lipozyme TLIM was the most effective in the present setting. Seven raffinose monoesters bearing alkyl chains varying from 6 to 18 carbons in length were prepared using the abovementioned protocols and obtained in yields ranging from $44 \%$ to $88 \%$. Each chromatographically purified ester was subjected to rigorous characterization involving ${ }^{1} \mathrm{H}$ NMR, ${ }^{13} \mathrm{C}$ NMR and hetereonuclear multiple bond correlation (HMBC) spectroscopic analyses. The derived data were in complete accord with the illustrated structures and the position of acylation was confirmed using HMBC techniques with the spectrum (Fig. 1) derived from 6-Omyristoylraffinose (RM) being representative of the series as a whole. Specifically, then, the methylene protons at C-6 within $\mathbf{R M}$ interact with the carbonyl carbon of the ester moiety and thus establishing the site of esterification as being at C6 of the galactose residue. Other key interactions allowed for the assignment of the resonances due to the non-hydroxylic protons associated with both the raffinose and the side-chain substructures.

\subsection{Surface-active properties}

The surface-active properties (as judged by their HLB values, water solubilities and CMCs) of raffinose esters RH to RS are shown in Table 1. The hydrophilic-lipophilic balance (HLB) is an empirical

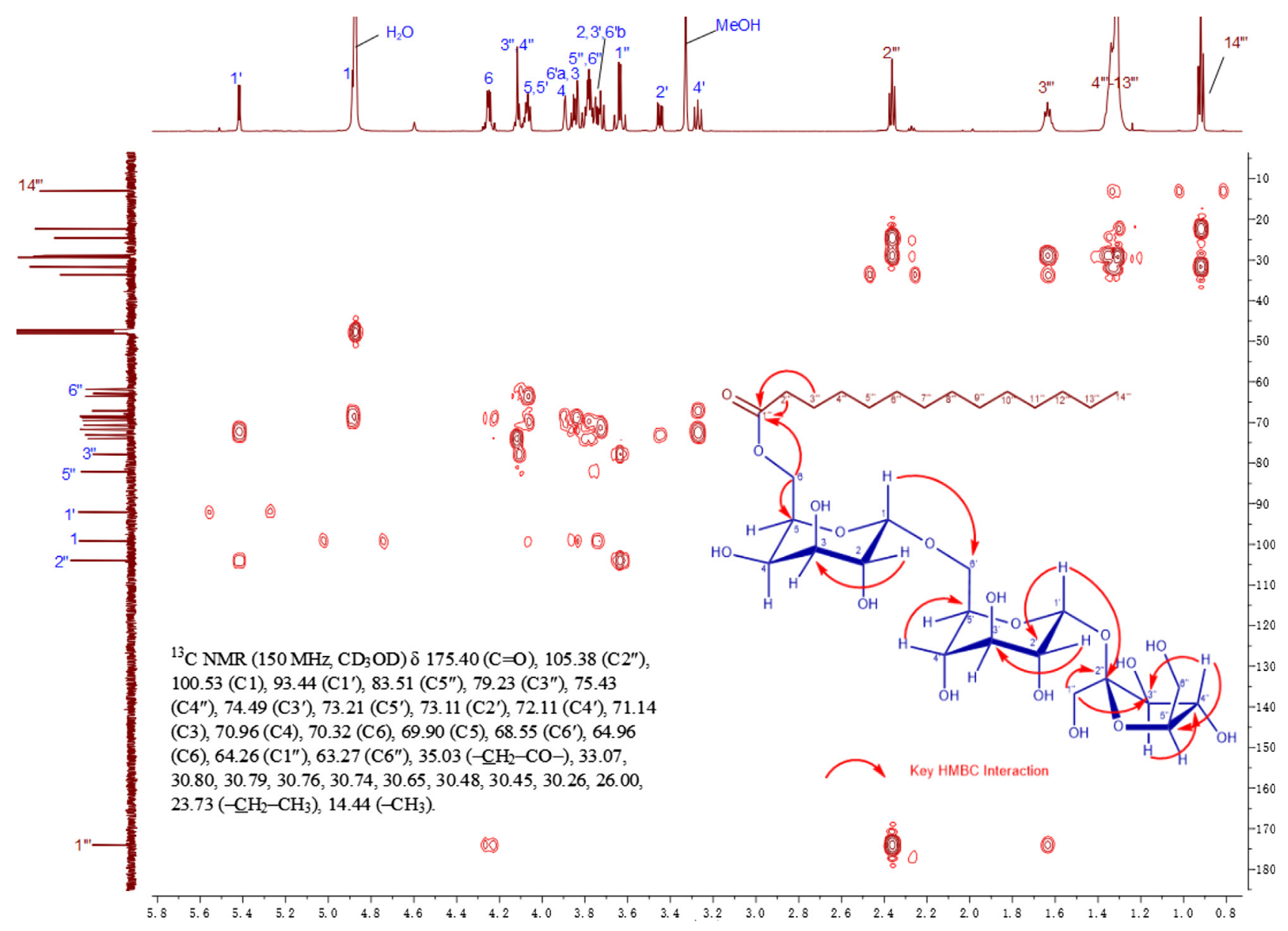

Fig. 1. Key $\mathrm{HMBC}$ correlations for 6-O-myristoylraffinose (RM). 
Table 1

HLBs, water solubilities, CMCs and $\gamma$ CMCs of esters RH to RS as well as those of the commercially-deployed sucrose esters P-1570 and P-1670.

\begin{tabular}{|c|c|c|c|c|c|}
\hline Sample & HLB measured $^{\mathrm{a}}$ & HLB Calcd. $^{\mathrm{b}}$ & Water solubility $(\mathrm{mg} / \mathrm{mL})$ & $\mathrm{CMC}(\mu \mathrm{M})$ & $\gamma_{\mathrm{CMC}}(\mathrm{mN} / \mathrm{m})$ \\
\hline RH & 19.5 & 16.7 & 1915.1 & 5896 & 39.2 \\
\hline RO & 17.4 & 16.0 & 1198.4 & 3755 & 25.9 \\
\hline RD & 15.3 & 15.3 & 931.6 & 1648 & 29.7 \\
\hline $\mathbf{R L}$ & 13.9 & 14.7 & 870.4 & 281 & 31.1 \\
\hline $\mathbf{R M}$ & 13.2 & 14.1 & 729.9 & 85 & 26.2 \\
\hline $\mathbf{R P}$ & 12.0 & 13.6 & 610.8 & 26 & 27.6 \\
\hline RS & 11.4 & 13.1 & 17.7 & 8 & 24.9 \\
\hline P-1570 & 15.2 & - & 215.8 & 34 & 36.7 \\
\hline P-1670 & 16.2 & - & 258.5 & 11 & 38.2 \\
\hline
\end{tabular}

a HLB values determined using the water number method.

b HLB values calculated by Griffin's method.

expression of the relationship between the hydrophilic and hydrophobic groups of a surfactant (the higher the HLB value, the more water-soluble the surfactant). It is one of the standard means for classifying surfactants, with a high HLB value being above 11 and a low one being below 9 [26]. Usually, HLBs are predicted by assigning values, as described by Griffin [27], to the given structure or by experimental measurement using, for example, the water number method [8]. Since raffinose is a trisaccharide containing a sucrose substructure, the higher hydrophilicity of raffinose (relative to sucrose) would be expected to result in higher HLB values for the corresponding esters. As shown in Table 1, the experimentally determined HLBs for esters RH to RS range from 19.5 to 11.4 . Such values, which were obtained by the two methods reveal, with some notable variations (see below), that the longer the alkyl chain associated with the fatty acid-derived residue the higher the HLB number. The experimentally determined HLB values of $\mathbf{R H}$ and $\mathbf{R O}$ were higher than the predicted ones while for RL, RM, RP and RS the situation was reversed. Broadly speaking, all seven esters can be regarded as hydrophilic with their measured HLB values indicating that they could serve as oil-in-water emulsifiers.

The water solubilities of esters RH to RS match their HLB profiles with $\mathbf{R H}$, incorporating the shortest side-chain, showing the best solubility (1915.1 mg/mL) and this being more than 100 -fold higher than that of $\mathbf{R S}(17.7 \mathrm{mg} / \mathrm{mL})$ bearing the longest alkyl side chain. Overall, the raffinose esters were significantly more water soluble than the commercial sucrose esters P-1570 (215.8 $\mathrm{mg} / \mathrm{mL}$ ) and P-1670 (258.5 mg/mL). Notably, while ester RD had a similar HLB value to that of P-1570, the water solubility of the former $(931.6 \mathrm{mg} / \mathrm{mL}$ ) compound was four times higher than the latter.

At a specific concentration, the so-called critical micelle concentration or CMC, surfactants combine to form micellar aggregates. This parameter is of practical importance since it indicates the concentration of a surfactant required to solubilize hydrophobic molecules in water [28]. In general, CMC values are correlated with the length of the hydrophobic moiety. That is to say, the longer the acyl chain, the lower the CMC [25]. As expected, the CMCs determined by the Wilhelmy plate method for the seven raffinose esters decreased from 5896 to $8 \mu \mathrm{M}$ on moving from 6-Ohexanoylraffinose (RH) to 6-O-stearoylraffinose (RS). Although this homologous series of raffinose monoesters covers a wide range of CMCs, only those incorporating a medium or long alkyl side-chain (i.e. RL, RM, RP and $\mathbf{R S}$ ) display the lower CMCs required to make them effective surfactants. While the $\gamma_{\mathrm{CMC}}$ values determined for esters RH to RS do not show any clear correlation with the length of the associated side-chains, certain of the raffinose monoesters exhibited, as detailed below, promising surface-active properties and thus making them very attractive non-ionic surfactants.

\subsection{Foaming properties}

Aerated food products are ubiquitous and encountered, for example, in bread, meringue and ice cream. Their aerated structures impart the light textural characteristics that make them popular among consumers [29]. The incorporation of gas bubbles as a full or partial replacement for dispersed fat droplets can be used to make foods with lower calorific content and that are, therefore, deemed healthier [30]. Accordingly, the creation and stabilization of foams is an important aspect of commercial food processing. Foams are often obtained through the use of low-molecular weight surfactants, amphiphilic polymers, proteins, and/or dispersed droplets $[31,32]$. The foaming properties of low-molecular weight surfactants are normally evaluated in terms of their "foamability" (the capacity to create foams) and "foaming stability" (FS), the latter being defined as the ability to maintain foams.

Accordingly, the foamabilities of raffinose monoesters RH to RS together with those of the three commercial controls P-1570, P1670 and Tween 20 were determined at concentrations of $0.2 \%$ and $0.5 \% \mathrm{w} / \mathrm{w}$. The results of such studies (Fig. 2a) revealed a modest positive correlation between foamability and sample concentration. The mono-esters RH and RO, embodying the smallest acyl moieties, exhibited no foamability even at $0.5 \% \mathrm{w} / \mathrm{w}$ concentrations, a situation that is attributed to their high-water solubilities. In contrast, ester RD started to show superior foamability (78.11\%) to the three positive controls at $0.2 \% \mathrm{w} / \mathrm{w}$ concentration and excellent foamability $(113.33 \%)$ at $0.5 \% \mathrm{w} / \mathrm{w}$ concentration. When the length of alkyl side chain increased to 12 carbons (as seen in $\mathbf{R L}$ ), then excellent foamability (131.89\%) was achieved at a lower concentration and this increased further (to 139.48\%) with RM displaying the best foamability at $0.2 \% \mathrm{w} / \mathrm{w}$ concentration. However, foamability was dramatically lower in those esters embodying longer alkyl side-chains, as seen in the case of RP (10.10\% and $18.33 \%$, at 0.2 and $0.5 \mathrm{w} / \mathrm{w}$ concentrations, respectively). Indeed, these values are lower than those of the positive controls at the same concentrations. RS, with the longest acyl chain, showed no foamability at the lower concentration and little $(11.67 \%)$ at the higher one. Presumably the significantly poorer foamabilities of esters RP and RS, viz. those possessing the longest fatty acid side-chains, can be attributed to their increased molecular size and relatively higher hydrophobicities (and that thus reduce both adsorption speed and transport rates to the interface) [33].

The foaming stabilities (FS) of esters RH to RS together with the three commercial controls P-1570, P-1670 and Tween 20 were measured over $10,20,30,40,50$, and $60 \mathrm{~min}$ at $0.2 \%$ and $0.5 \%$ $\mathrm{w} / \mathrm{w}$ concentrations and the outcomes of the relevant experiments are shown in Fig. 2b and 2c. These reveal that, at low concentra- 

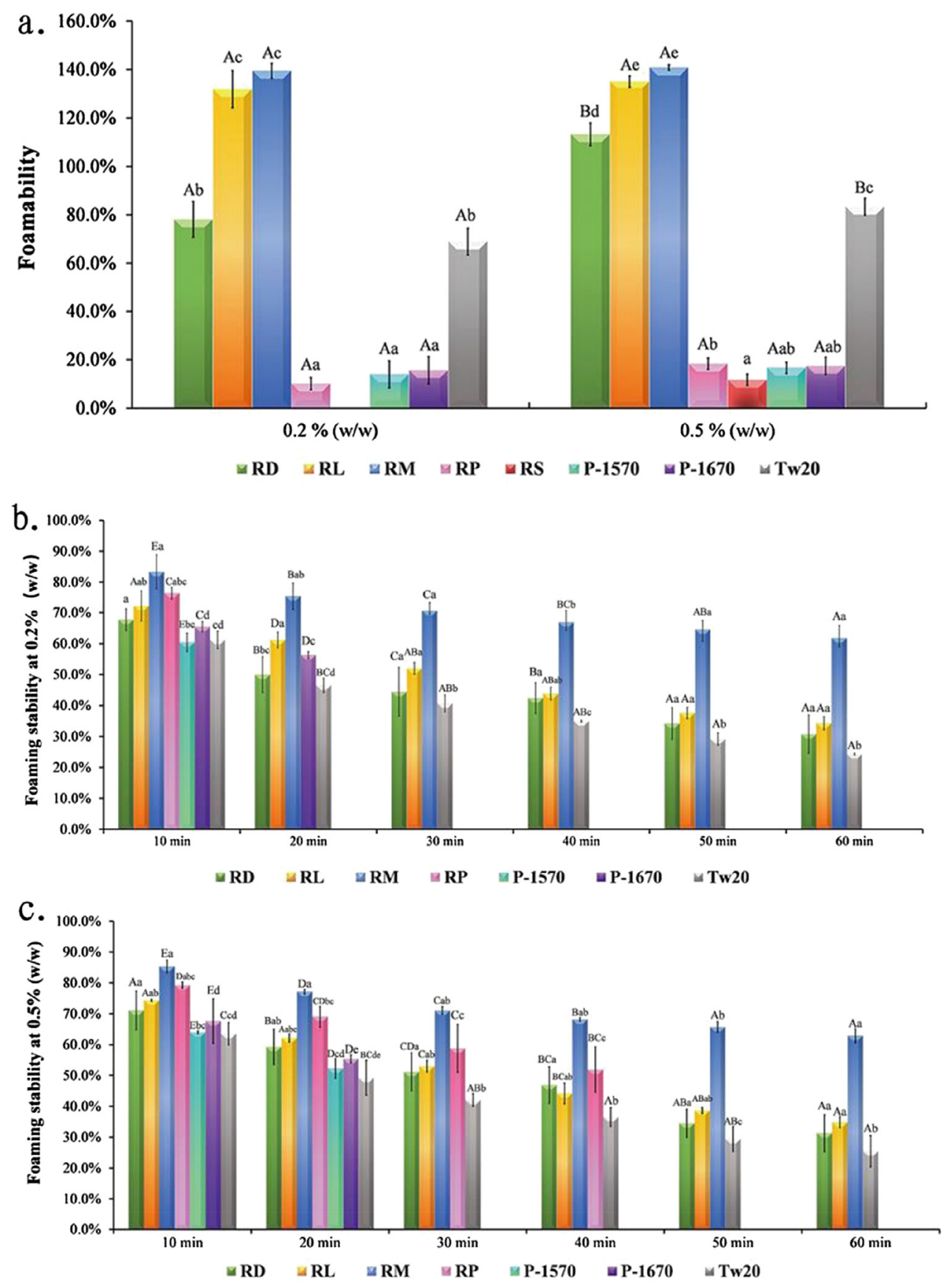

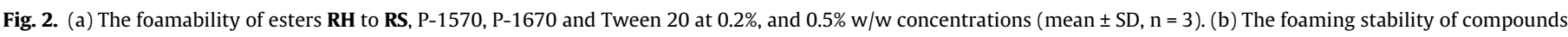

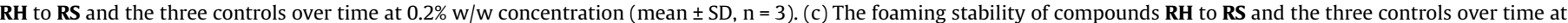

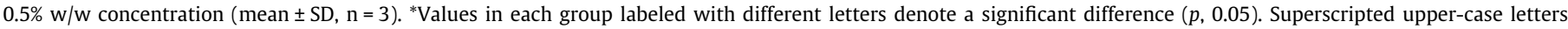

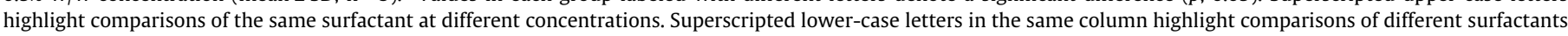
at the same concentration.

tion, it is not possible to maintain a foam with the commercial sucrose ester P-1570 or RP for even just $20 \mathrm{~min}$. Similarly, the foam stabilized by the other sucrose-based control (viz. P-1670) collapsed within $30 \mathrm{~min}$. This means that raffinose monoesters RD, RL and RM exhibit superior FSs to all three positive controls over any given period. RM showed the highest FS values (of $83.36 \%$, $75.38 \%, 70.65 \%, 66.95 \%, 64.58 \%$ and $61.82 \%$ over $10,20,30,40,50$ and $60 \mathrm{~min}$, respectively). After standing for $60 \mathrm{~min}$, the foam height of the system obtained using this ester was about threetimes that of the one derived from Tween 20. At higher concentrations the trends were similar save that the RP-derived systems started to show superior FSs to those involving RD and the twosucrose ester-based controls. This system was found to be superior to that obtained from Tween 20 although the foam collapsed after 50 min. Overall, the FS values seemed uncorrelated with the concentrations of the relevant mono-ester, especially for those with excellent properties, namely those derived from RO, RL, RM and Tween 20. Such observations are rather difficult to rationalize, but it is conceivable that the foamability and foaming stability of such systems arise through the operation of a variety of factors, including the adsorption capacity of the surfactants at the air/ water interface, the rheological properties at the interface and 
the rate of diffusion of the gas captured in the foam [32]. The precise interplay of such factors clearly requires further study from both the experimental and theoretical perspectives. Nevertheless, the present results reinforce the notion that raffinose monoesters embodying the appropriate acyl moiety can act as excellent foaming agents and so have real potential in the food industry.

\subsection{The shelf-life of the $\boldsymbol{R H}$-RS- stabilized emulsions during storage}

An emulsion is a mixture of two or more liquids that are not normally miscible. Emulsion droplet stabilization is often achieved through the addition of amphiphilic molecules such as emulsifiers that serve to decrease the interfacial tension between the immiscible phases and/or increase the steric hindrance and/or the electrostatic repulsion between the constituent droplets [34]. How long an emulsified state can be maintained is a key issue associated with the development of new food emulsifiers [35] and emulsion droplet-size distribution analyses has been employed for quantitating such properties. In the present study, such analyses were applied to the raffinose monoesters. This involved determining droplet diameters, droplet-size distributions and variations in the appearance, over a 13 day storage period, of a "blank" sample with those emulsions formed using compounds RH to RS or the commercially deployed surfactants P-1670 and Tween 20 [36,37].

Due to the significant hydrophilic nature of the raffinose esters an oil loading of $5 \%$ was employed while an optimized concentration of $0.3 \%$ was used for each test sample. The results of such studies, which are presented in Fig. 3, Fig. 4 and Table 2, established the droplet diameter, droplet-size distribution and appearance associated with the various emulsions. In terms of appearance and droplet diameter (Fig. 4 and Table 2), the emulsions formed using esters RH to RD (C6-C10) or the control (Tween20) resulted in stratification over the 13 day storage period. In particular, the emulsions involving RH and RO (C6-C8) stratified on the second day, while that derived from RD (C10) started to stratify on the fifth day of storage (the one obtained using Tween 20 showed signs of stratification on the seventh day). As can be discerned from Table 2, no significant changes in droplet diameter were observed during storage. So, for example, the size of the RL (C12)-derived droplets was $179.6 \mathrm{~nm}$ on the first day and $183.7 \mathrm{~nm}$ on the thirteenth day. Similarly, those involving RS (C18) had diameters of 168.4 and $167.2 \mathrm{~nm}$ at the same time points. Among the other emulsions, the diameter of droplets decreased, from $179.6 \mathrm{~nm}$ (RL) to $168.4 \mathrm{~nm}(\mathbf{R S})$, as the alkyl chain increased indicating that longer hydrophobic chains enhance the stability of the derived emulsions.

As is clear from the data presented in Fig. 3, the blank, RH and RO-derived emulsions showed similar trimodal distributions of droplet-sizes after 1 day, indicating the unstable nature of these systems. This instability can be attributed to the coalescence of oil droplets and oiling off as a result of the $\mathbf{R H}$ and RO-derived systems (that possess the shortest alkyl side-chains) being unable to form a complete interfacial layer around the oil droplet [38]. The appearance, over time, of peaks on the right-hand-side of the original distribution and the obvious bimodal nature of the RD-derived emulsion after three days suggested the presence of droplets that have not been completely covered by the surfactants and have thus undergone coalescence [39]. Indeed, these four emulsions showed the largest mean droplet diameters [from 221.6 to $399.8 \mathrm{~nm}$ (Table 2)] and complete oil-water layer separation (Fig. 4) after 1-5 days. When the length of side-chain reached 12,14 or 16 carbons, as seen in esters $\mathbf{R L}, \mathbf{R M}$, and $\mathbf{R P}$ respectively, relatively stable droplet distributions as well as smaller mean droplet diameters were observed over a 5 day period, indicating that they effectively prevent droplet aggregation [40]. That said, traces of larger droplets were formed after 13 days. As for the RS-derived emulsion
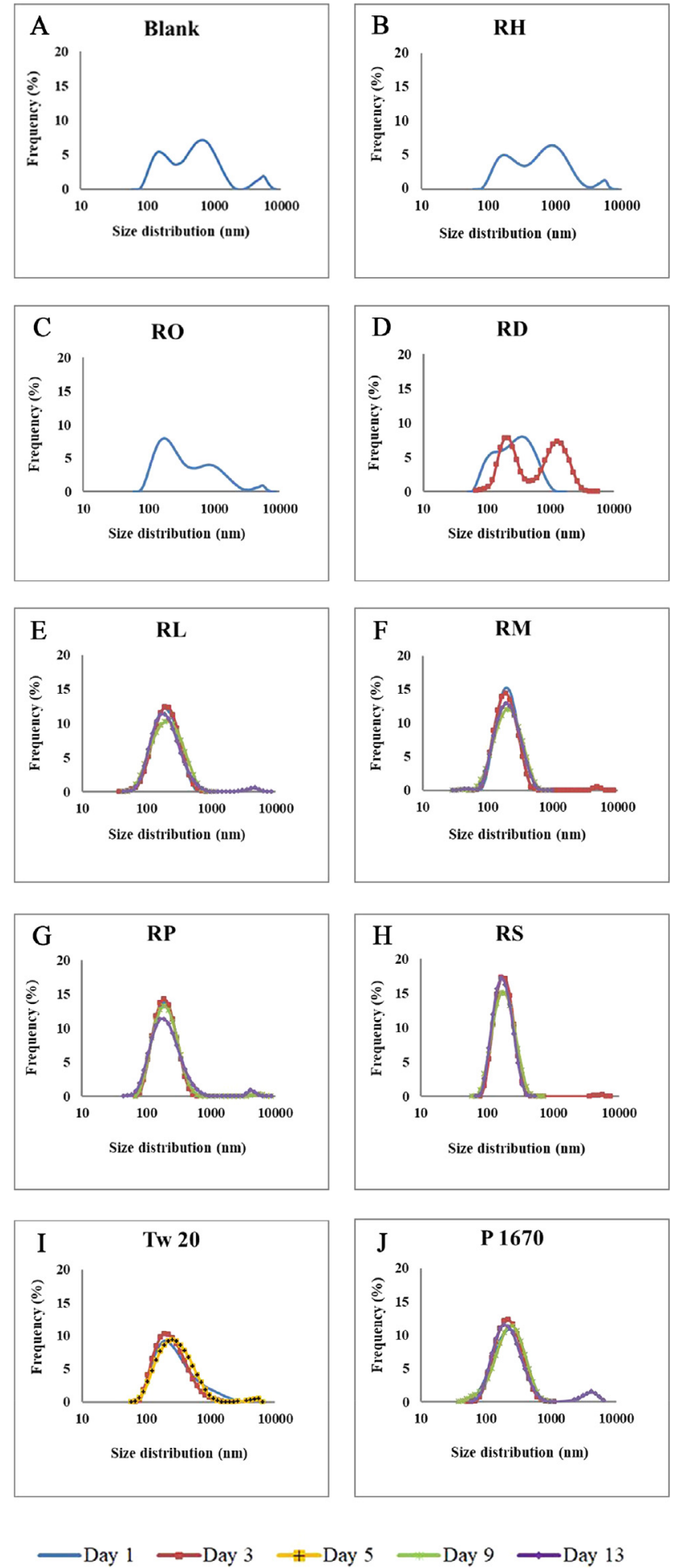

Fig. 3. Droplet size distribution, over time, of the oil-in-water emulsion systems formed using compounds RH to RS (A-H), the commercial emulsifier Tween 20 (I) and the sucrose ester P-1670 (J).

(viz. that formed using the surfactant with the longest side-chain), this displayed the smallest mean droplet diameters (Table 2) and there were no pronounced changes in the droplet-size distributions over 13 days. This suggests ester $\mathbf{R S}$ has excellent emulsifying potency. In terms of mean droplet diameter, all of the RL, RM, RP and RS-derived emulsions were superior to those derived from the commercial controls. For instance, the emulsion derived from 


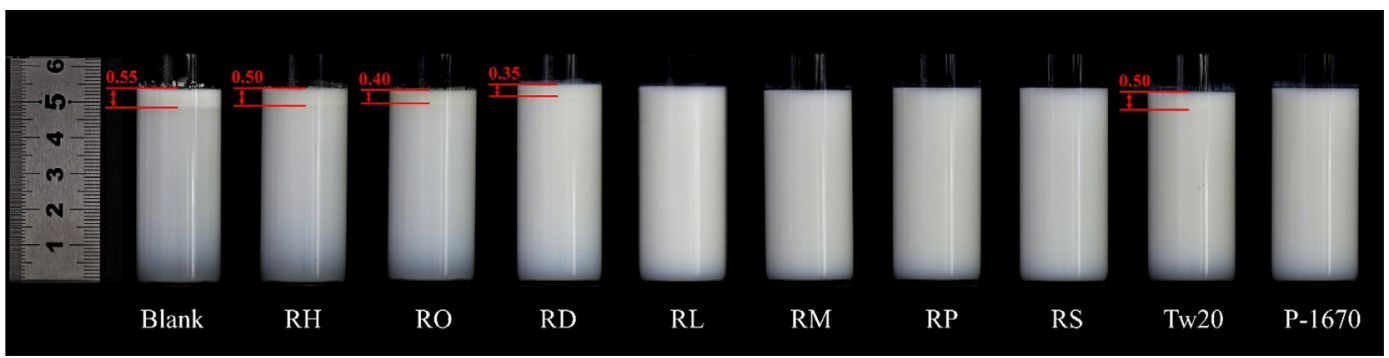

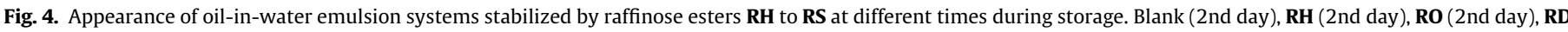

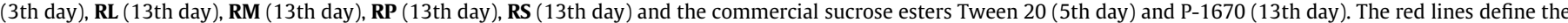

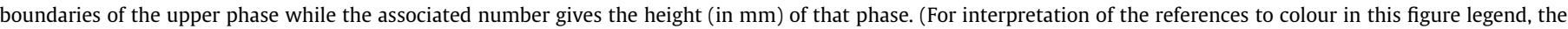
reader is referred to the web version of this article.)

Table 2

The mean diameter of droplets formed in RH to RS ester-stabilized emulsions at varying times (in days).

\begin{tabular}{|c|c|c|c|c|c|c|c|c|c|}
\hline & \multicolumn{9}{|c|}{ Mean droplet diameter (nm) } \\
\hline & Day 1 & Day 2 & Day 3 & Day 4 & Day 5 & Day 7 & Day 9 & Day 11 & Day 13 \\
\hline Blank & $354.4 \pm 6.313$ & $\mathrm{SE}^{*}$ & SE & SE & SE & SE & SE & SE & SE \\
\hline RH & $399.8 \pm 9.058$ & SE & SE & SE & SE & SE & SE & SE & SE \\
\hline RO & $295.2 \pm 14.98$ & SE & SE & SE & SE & SE & SE & SE & SE \\
\hline RD & $221.6 \pm 1.897$ & $220.5 \pm 6.353$ & $225.5 \pm 1.947$ & $239.1 \pm 2.053$ & SE & SE & SE & SE & SE \\
\hline $\mathbf{R L}$ & $179.6 \pm 1.550$ & $180.9 \pm 3.555$ & $181.2 \pm 1.473$ & $182.9 \pm 2.987$ & $183.2 \pm 3.081$ & $182.1 \pm 2.715$ & $183.1 \pm 2.307$ & $182.3 \pm 0.896$ & $183.7 \pm 3.350$ \\
\hline $\mathbf{R M}$ & $177.8 \pm 1.715$ & $176.8 \pm 3.915$ & $177.8 \pm 1.537$ & $186.5 \pm 2.715$ & $181.7 \pm 2.548$ & $181.9 \pm 4.592$ & $183.5 \pm 2.931$ & $185.7 \pm 1.966$ & $183.4 \pm 1.852$ \\
\hline $\mathbf{R P}$ & $178.0 \pm 1.557$ & $183.3 \pm 1.916$ & $179.0 \pm 2.359$ & $183.0 \pm 2.765$ & $180.2 \pm 3.636$ & $183.1 \pm 1.528$ & $182.8 \pm 0.473$ & $183.8 \pm 2.230$ & $182.8 \pm 1.067$ \\
\hline RS & $168.4 \pm 1.309$ & $168.9 \pm 2.805$ & $170.9 \pm 1.457$ & $169.9 \pm 1.129$ & $171.4 \pm 0.384$ & $168.8 \pm 1.162$ & $169.4 \pm 2.262$ & $167.2 \pm 1.133$ & $165.7 \pm 0.902$ \\
\hline Tw 20 & $225.3 \pm 2.999$ & $224.5 \pm 1.453$ & $231.8 \pm 3.384$ & $235.5 \pm 2.538$ & $245.8 \pm 1.744$ & SE & SE & SE & SE \\
\hline P-1670 & $195.9 \pm 0.891$ & $201.8 \pm 3.193$ & $199.0 \pm 0.929$ & $198.1 \pm 0.802$ & $201.2 \pm 1.493$ & $199.4 \pm 0.954$ & $212.9 \pm 2.401$ & $207.1 \pm 2.553$ & $212.9 \pm 5.839$ \\
\hline
\end{tabular}

SE: stratified emulsion.

Tween 20 showed increasing mean droplet diameters $(225.3 \mathrm{~nm}$ on the first day and $245.8 \mathrm{~nm}$ on the fifth day) with complete oil-water layer separation eventually being observed. In the case of the P-1670-derived emulsion a growing bimodal droplet diameter distribution was observed as well as an increasing mean droplet diameter indicating that partial aggregation of the oil droplets was occurring over the storage period (Table 2). As such, P-1670 must be regarded as an inferior surfactant relative to certain of raffinose esters, at least at the same concentration and at neutral $\mathrm{pH}$

On the basis of the foregoing, we conclude that the acyl chains associated with the raffinose monoesters have significant effects on droplet diameters and distributions $(P<0.05)$ in the derived emulsions. Thus, the raffinose monoesters RL, RM, RP and RS showed superior emulsion stabilizing properties when compared to those congeners embodying shorter acyl chains and to the commercial sucrose ester P-1670. This is almost certainly because of, (i), their stronger hydrophobic interactions with the oil droplets (and thus significantly reducing rates of coalescence) [25] and, (ii), steric effects that inhibit droplet aggregation [41]. In recent work, Ren and co-workers [39] compared the emulsion stabilization effects of certain glucose-derived esters with those of their commercially available and sucrose-based counterparts and found that the latter ones display greater "potencies" and probably, in part at least, because of their greater molecular sizes. In this study, it is observed that the raffinose-based esters are better emulsifiers than the sucrose-based ones and presumably for the same reasons.

\subsection{Influence of environmental stress on stability of the $\boldsymbol{R} \boldsymbol{L}$ to $\boldsymbol{R S}$ - derived emulsions}

The capacity to deploy the title emulsifying agents in industrial settings will be influenced by a range of environmental factors including the $\mathrm{pH}$, temperature and ionic strength of the systems involved. Accordingly, we have investigated the effect of such factors on the stability of the $\mathbf{R L}$ to $\mathbf{R S}$-ester derived emulsions and detail the outcomes of relevant studies here.

\subsubsection{Influence of $\mathrm{pH}$}

The variation in the mean diameter of the droplets within emulsions, that can be taken as an indication of their stability, was measured periodically at varying $\mathrm{pH}(2-8)$ during storage at ambient temperatures. The outcomes of such studies are shown in Fig. 5 (a) and Table 2 and reveal no dramatic change in the droplet diameters of the different raffinose ester-derived emulsions during the storage period. The appearances of the RL to RS-ester derived emulsions in the pH range $4-10$ is shown in Fig. 5(a) and reveal significant effects. So, for example, the emulsion involving RL stratified over the 6-8 range and formed yellow oil droplets in the upper layer between pH 6 and 10 while that produced using RM was relatively stable over the same range and only stratified at $\mathrm{pH}$ 4. Further, the RP, RS and P-1670-derived systems formed stable emulsions in the range $\mathrm{pH}$ 8-10 while stratification emerged between 4 and 6 . As such, those esters incorporating longer alkyl side chains appear capable of forming more stable emulsions over a wider $\mathrm{pH}$ range. In the cases of those emulsions derived from RP and $\mathbf{R S}$, under acidic conditions aggregation resulting in stratification was observed but relatively stable systems were obtained under neutral and alkaline conditions. This is attributed to the droplets stabilized by the non-ionic surfactants still being charged due to the presence of ionizable surface active impurities (such as free fatty acids) and/or the preferential adsorption, at low $\mathrm{pH}$, of protons $\left(\mathrm{H}^{+}\right)$on the droplet surfaces [42]. In the case of the stable systems (derived from esters $\mathbf{R M}$ to $\mathbf{R S}$ ), there was no difference in droplet diameter in the $\mathrm{pH}$ range $6-10$, their sizes only varying between 176 and $185 \mathrm{~nm}$. As such the $\mathrm{pH}$ of any given system only affects emulsion stability and not droplet diameter. The relatively poor acid-stability of emulsions formed from so-called bio-based surfactants has been reported before and this feature is attributed 

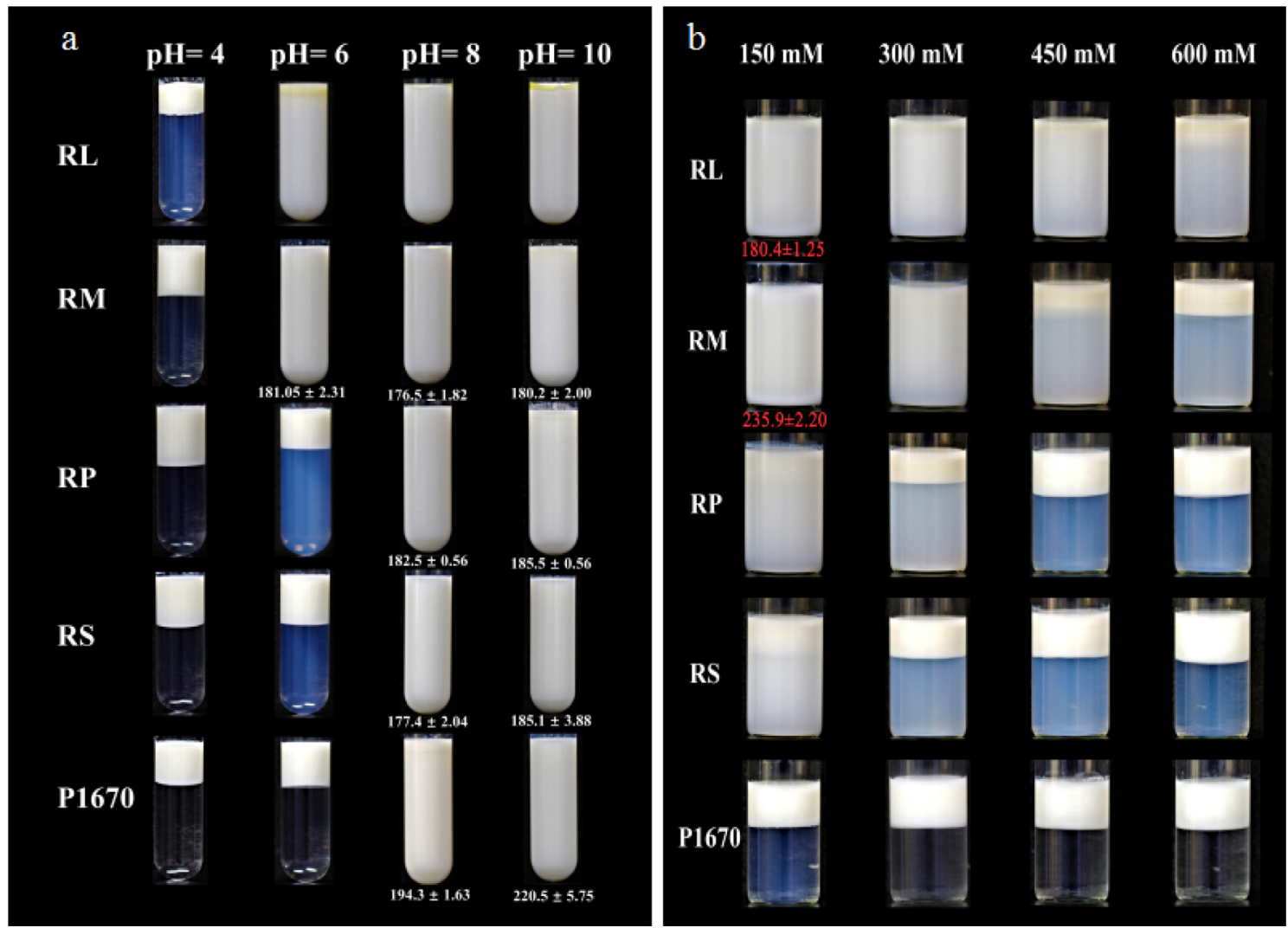

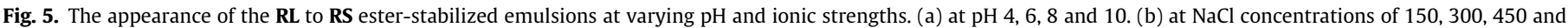
$600 \mathrm{mM}$. The sucrose ester P-1670 was used as a positive control in both instances.

to the weakening of the electrostatic repulsion between the droplets at low $\mathrm{pH}$ values [40].

\subsubsection{Influence of temperature}

Temperature can be a key factor affecting emulsion stability. Accordingly, we investigated the effect of different temperatures $\left(25,50,70,90^{\circ} \mathrm{C}\right)$ on the droplet diameter and distribution within those emulsions formed using esters RL to RS. The mean droplet diameters of such oil-in-water emulsions at different temperatures are shown in Table 3. In essence, no significant variation in droplet diameter was observed across the series at any given temperature. In contrast, the droplet diameter of the RL-stabilized emulsion increased from 178.4 to $194.5 \mathrm{~nm}$ on heating the system from 25 to $50^{\circ} \mathrm{C}$ and then remained at essentially this value $(192.2 \mathrm{~nm})$ up to $90^{\circ} \mathrm{C}$. This means that the $\mathbf{R L}$-based system is unstable at the lower temperatures (viz. in the $25-50{ }^{\circ} \mathrm{C}$ range). In contrast, the droplet-size of $\mathbf{R M}$-stabilized emulsions did not change over the $25-50{ }^{\circ} \mathrm{C}$ range and decreased (from 176.2 to $168.9 \mathrm{~nm}$ ) between 50 and $70^{\circ} \mathrm{C}$. A similar result was reported by Rao et al. [43] who noted that when $10 \%$ sucrose monopalmitate was incorporated into a microemulsion then a decrease in mean droplet diameter occurred and greater turbidity was observed as the temperature of the system was increased. In the case of the RP and RSderived systems no significant change in droplet diameter was observed over the $25-90{ }^{\circ} \mathrm{C}$ range and so indicating they are thermally robust. In contrast, the droplet diameter of the P-1670stabilized emulsion increased from 194.2 to $203.9 \mathrm{~nm}$ between 70 and $90^{\circ} \mathrm{C}$ and so suggesting this system is unstable above $70{ }^{\circ} \mathrm{C}$.

The size distributions of the droplets associated with the $\mathbf{R} \mathbf{L}$ to RS ester-stabilized emulsions observed at $25,50,70$ and $90{ }^{\circ} \mathrm{C}$ are shown in Fig. 6, and reveal that temperature impacts on the droplet sizes in the RL and P-1670-derived systems but not in those involving esters $\mathbf{R M}$ to $\mathbf{R S}$. In addition, the droplet sizes associated with the P-1670-associated emulsions were more widely distributed over this temperature range. In the case of the RLstabilized emulsions a distinct tail to the distribution was observed over the $50-90^{\circ} \mathrm{C}$ portion of the temperature range and indicating that stratification was beginning to occur at the higher temperatures (and as a result of an increase in oil droplet diameter).

\subsubsection{Influence of ionic strength}

Salt is often added to foods, medicines and cosmetics that embody colloidal systems. In food, salt enters the digestive system and so affecting taste as well as metabolic function. As such it was important to assess the impact of varying ionic strength on the RH to RS ester-derived emulsions and relevant tests were conducted at neutral $\mathrm{pH}$ (viz. at $\mathrm{pH} 7$ ) and the outcomes of these are summarized in Fig. 5(b). So, the RL-derived emulsion was found to be relatively stable at varying ionic strengths (from $150 \mathrm{mM}$ to $600 \mathrm{mM}$ ) but as the carbon chain of the associated ester increased then stratification effects emerged at higher salt concentrations and such that RS was unable to stabilize the associated emulsion even at $150 \mathrm{mM}$. As phase separation proceeded the aqueous phase developed a blue coloration and this disappeared when the process was complete. The average droplet diameters associated with the RL and RM-derived emulsions were $180.4 \mathrm{~nm}$ and $235.9 \mathrm{~nm}$, respectively, at $150 \mathrm{mM}$ and each of these increased at higher ionic strength. Significantly, the P1670-based system was unable to form a stable emulsion across the full $150-600 \mathrm{mM}$ concentration range. The adverse effects of increasing ionic strength on emulsion stabilities have been reported previously [43] and are attributed to electrostatic repulsion between the negatively droplets at increasing salt concentrations [44]. 
Table 3

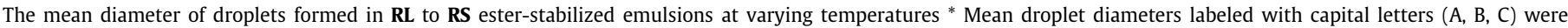

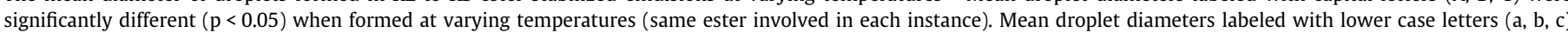
were significantly different $(p<0.05)$ when varying esters were used at the same temperature.

\begin{tabular}{|c|c|c|c|c|}
\hline & \multicolumn{4}{|c|}{ Mean droplet diameter (nm) } \\
\hline & $25^{\circ} \mathrm{C}$ & $50^{\circ} \mathrm{C}$ & $70^{\circ} \mathrm{C}$ & $90{ }^{\circ} \mathrm{C}$ \\
\hline $\mathbf{R L}$ & $178.4 \pm 2.68^{\mathrm{Aa}}$ & $194.5 \pm 5.81^{\mathrm{Bb}}$ & $196.1 \pm 1.31^{\mathrm{Bc}}$ & $196.2 \pm 2.73^{\mathrm{Bc}}$ \\
\hline $\mathbf{R M}$ & $177.8 \pm 1.54^{\mathrm{Aa}}$ & $176.2 \pm 2.83^{\mathrm{Aa}}$ & $168.9 \pm 4.57^{\mathrm{Ba}}$ & $169.5 \pm 0.78^{\mathrm{Ba}}$ \\
\hline $\mathbf{R P}$ & $177.8 \pm 1.45^{\mathrm{Aa}}$ & $180.7 \pm 3.26^{\mathrm{Aa}}$ & $183.1 \pm 5.41^{\mathrm{Ab}}$ & $181.4 \pm 0.64^{\mathrm{Ab}}$ \\
\hline RS & $177.0 \pm 1.19^{\mathrm{Aa}}$ & $175.6 \pm 2.51^{\mathrm{Aa}}$ & $177.7 \pm 3.01^{\mathrm{Ab}}$ & $176.4 \pm 5.33^{\mathrm{Ab}}$ \\
\hline P-1670 & $195.7 \pm 0.40^{\mathrm{Ab}}$ & $194.2 \pm 5.76^{\mathrm{Ab}}$ & $194.4 \pm 1.84^{\mathrm{Ac}}$ & $203.9 \pm 4.15^{\mathrm{Bc}}$ \\
\hline
\end{tabular}
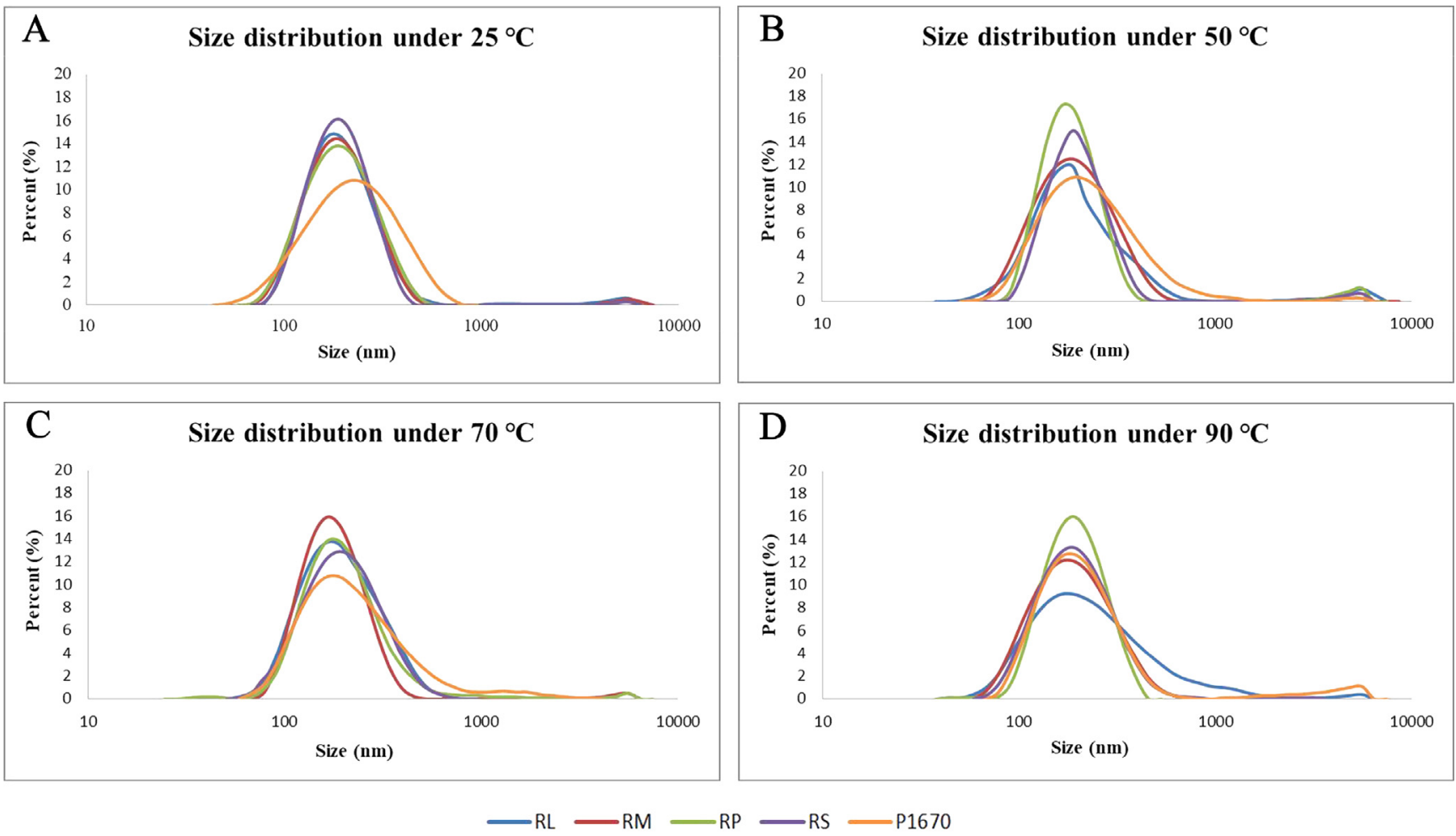

\section{$\longrightarrow$ RS P1670}

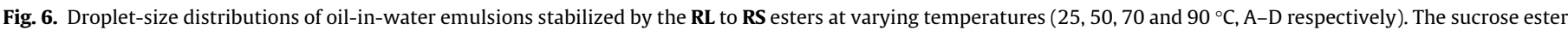
$\mathrm{P}-1670$ was used as a positive control in all cases.

\section{Conclusions}

In this study, we have detailed the synthesis of a series of raffinose monoesters incorporating differing fatty acid residues and an investigation of their properties as surfactants. We have found that such raffinose esters embodying appropriately hydrophobic acyl side-chains display distinctive and excellent surfactant effects, especially in oil-in-water emulsions. Previously, we have shown that certain disaccharide (lactose, maltose)-derived esters exhibit emulsifying properties superior to those of their commerciallydeployed and sucrose-based counterparts $[4,8]$. Similar to such earlier observations $[4,8,25]$, we have now found that the performance of raffinose monoesters as surfactants is largely determined by the length of the associated acyl chain. The structure-property profile of these raffinose esters, as established in the present study, can be summarized as follows: (i) when the length of the acyl chain increases, their HLB values, CMCs and water solubilities decrease (a trend in accord with previous findings on other sugar esters $[4,5,8,25])$; (ii) raffinose esters with medium length acyl chains (viz. those embodying 12 or 14 carbons) display the best foamability as well as foaming stability (a feature also consistent with previous observations made on lactose [8] and maltose [4] based esters); (iii) the stabilities of the raffinose ester-stabilized emulsions increased as the acyl chain became longer, (a trend counter to that observed with the esters of lactose [8] and maltose [4] but in line that seen in the glucose ester series [39]). The emulsions stabilized by raffinose monoesters were generally sensitive to strongly acidic conditions and high ionic strength but relatively stable across temperatures between 25 and $90^{\circ} \mathrm{C}$. Overall, then, 6-O-acylraffinose esters embodying appropriately long acyl chains can serve a effective surfactants at or above neutral $\mathrm{pH}$ and up to $90{ }^{\circ} \mathrm{C}$. These results should serve as a useful guide for the development of raffinose esters as emulsifiers in the food industry.

\section{Conflict of Interest Statement}

The authors declare no competing financial interest.

\section{Acknowledgement}

The authors thank the Program for Guangdong Pearl River Introducing Innovative and Entrepreneurial Teams (grant 2017ZT07C571), the Program for Guangdong YangFan Introducing 
Innovative and Entrepreneurial Teams (grant 2016YT03H132), and the Fundamental Research Funds for the Central Universities (grant 21617327) for financial support.

\section{Appendix A. Supplementary material}

Supplementary data to this article can be found online at https://doi.org/10.1016/j.jcis.2019.08.070.

\section{References}

[1] S. Lucarini, L. Fagioli, R. Cavanagh, W. Liang, D. Perinelli, M. Campana, S Stolnik, J. Lam, L. Casettari, A. Duranti, Synthesis, structure-activity relationships and in vitro toxicity profile of lactose-based fatty acid monoesters as possible drug permeability enhancers, Pharmaceutics 10 (3) (2018) 81

[2] M.F. Gutiérrez, J.L. Rivera, A. Suaza, A. Orjuela, Kinetics of the transesterification of methyl palmitate and sucrose using surfactants, Chem. Eng. J. 347 (2018) 877-888.

[3] F.J. Plou, M.A. Cruces, M. Ferrer, G. Fuentes, E. Pastor, M. Bernabé, M. Christensen, F. Comelles, J.L. Parra, A. Ballesteros, Enzymatic acylation of diand trisaccharides with fatty acids: choosing the appropriate enzyme, support and solvent, J. Biotechnol. 96 (1) (2002) 55-66.

[4] Y.-R. Ma, M.G. Banwell, R. Yan, P. Lan, Comparative study of the emulsifying properties of a homologous series of long-chain 6'-O-acylmaltose esters, J. Agric. Food Chem. 66 (33) (2018) 8832-8840.

[5] X. Zhang, W. Wei, X. Cao, F. Feng, Characterization of enzymatically prepared sugar medium-chain fatty acid monoesters, J. Sci. Food Agric. 95 (8) (2015) $1631-1637$.

[6] X. Zhang, F. Song, M. Taxipalati, W. Wei, F. Feng, Comparative study of surfaceactive properties and antimicrobial activities of disaccharide monoesters, PLoS One 9 (12) (2014) e114845.

[7] A. Wagh, S. Shen, F.A. Shen, C.D. Miller, M.K. Walsh, Effect of lactose monolaurate on pathogenic and nonpathogenic bacteria, Appl. Environ. Microbiol. 78 (9) (2012) 3465-3468.

[8] M.-Y. Liang, M.G. Banwell, Y. Wang, P. Lan, Effect of variations in the fatty acid residue of lactose monoesters on their emulsifying properties and biological activities, J. Agric. Food Chem. 66 (47) (2018) 12594-12603.

[9] T. Ikekawa, N. Abiko, F. FuKUo, Ehrlich ascites tumor effect and chromatographic behaviors of fatty acyl monoesters of sucrose and trehalosem, Chem. Pharm. Bull. 25 (1977) 1717-1724.

[10] D. Perinelli, S. Lucarini, L. Fagioli, R. Campana, D. Vllasaliu, A. Duranti, Casettari, Lactose oleate as new biocompatible surfactant for pharmaceutical applications, Eur. J. Pharm. Biopharm. 124 (2018) 55-62.

[11] I. Pérez-Victoria, F.J. Pérez-Victoria, S. Roldán-Vargas, R. García-Hernández, L. Carvalho, S. Castanys, F. Gamarro, J.C. Morales, J.M. Pérez-Victoria, Nonreducing trisaccharide fatty acid monoesters: novel detergents in membrane biochemistry, Biochim. Biophys. Acta (BBA)-Biomembr. 1808 (3) (2011) 717 726.

[12] L. Carvalho, J.C. Morales, J.M. Pérez-Victoria, I. Pérez-Victoria, Hemolytic activity and solubilizing capacity of raffinose and melezitose fatty acid monoesters prepared by enzymatic synthesis, Biochim. Biophys. Acta 92 (2015) 139-145.

[13] Y. Chen, P. Lan, Total syntheses and biological evaluation of the ganoderma lucidum alkaloids lucidimines B and C, ACS Omega 3 (3) (2018) 3471-3481.

[14] S.H. Al-Sheraji, A. Ismail, M.Y. Manap, S. Mustafa, R.M. Yusof, F.A. Hassan, Prebiotics as functional foods: a review, J. Funct. Foods 5 (4) (2013) 1542 1553.

[15] S.I. Mussatto, I.M. Mancilha, Non-digestible oligosaccharides: a review, Carbohyd. Polym. 68 (3) (2007) 587-597.

[16] H.N. Johansen, V. Glitsø, K.E. Bach Knudsen, Influence of extraction solvent and temperature on the quantitative determination of oligosaccharides from plant materials by high-performance liquid chromatography, J. Agric. Food Chem. 44 (6) (1996) 1470-1474.

[17] B.-B. Fei, L. Ling, C. Hua, S.-Y. Ren, Effects of soybean oligosaccharides on antioxidant enzyme activities and insulin resistance in pregnant women with gestational diabetes mellitus, Food Chem. 158 (2014) 429-432.

[18] I. Pérez-Victoria, J.C. Morales, Complementary regioselective esterification of non-reducing oligosaccharides catalyzed by different hydrolases, Tetrahedron 62 (5) (2006) 878-886.
[19] I. Pérez-Victoria, J.C. Morales, Regioselectivity in acylation of oligosaccharides catalyzed by the metalloprotease thermolysin, Tetrahedron 62 (10) (2006) 2361-2369.

[20] S. Riva, M. Nonini, G. Ottolina, B. Danieli, Subtilisin-catalyzed esterification of di-and oligosaccharides containing a D-fructose moiety, Carbohyd. Res. 314 (3-4) (1998) 259-266.

[21] Y. Lu, R. Yan, X. Ma, Y. Wang, Synthesis and characterization of raffinose fatty acid monoesters under ultrasonic irradiation, Eur. Food Res. Technol. 237 (2) (2013) 237-244.

[22] Y. Lu, R. Yan, X. Ma, Y. Wang, Y. Sun, Z. Luo, Enzymatic hydrolysis preparation of mono-O-lauroylsucrose via a mono-O-lauroylraffinose intermediate, J. Agric. Food Chem. 61 (39) (2013) 9412-9420.

[23] C. Besset, S. Chambert, Y. Queneau, S. Kerverdo, H. Rolland, J. Guilbot, Reactivity of melezitose and raffinose under Mitsunobu reaction conditions, Carbohyd. Res. 343 (5) (2008) 929-935.

[24] R. Gupta, K. James, F. Smith, Sucrose esters and sucrose ester/glyceride blends as emulsifiers, J. Am. Oil Chem. Soc. 60 (4) (1983) 862-869.

[25] M. Ferrer, F. Comelles, F.J. Plou, M.A. Cruces, G. Fuentes, J.L. Parra, A. Ballesteros, Comparative surface activities of di-and trisaccharide fatty acid esters, Langmuir 18 (3) (2002) 667-673.

[26] A.H. Chun, A.N. Martin, Measurement of hydrophile-lipophile balance of surface-active agents, J. Pharm. Sci.-U.S. 50 (9) (1961) 732-736.

[27] W.C. Griffin, Classification of surface-active agents by“ HLB”, J. Soc. Cosmet. Chem. 1 (1949) 311-326.

[28] T. Plat, R.J. Linhardt, Syntheses and applications of sucrose-based esters, J. Surfactants Deterg. 4 (4) (2001) 415-421.

[29] J.-B. Bezelgues, S. Serieye, L. Crosset-Perrotin, M. Leser, Interfacial and foaming properties of some food grade low molecular weight surfactants, Colloid Surf. A $331(1-2)(2008)$ 56-62.

[30] E. Dickinson, Food emulsions and foams: stabilization by particles, Curr. Opin. Colloid In. 15 (1-2) (2010) 40-49.

[31] R. Heymans, I. Tavernier, S. Danthine, T. Rimaux, P. Van der Meeren, K. Dewettinck, Food-grade monoglyceride oil foams: the effect of tempering on foamability, foam stability and rheological properties, Food Funct. 9 (6) (2018) 3143-3154.

[32] F.C. Zhan, J. Li, Y.T. Wang, M.Q. Shi, B. Li, F. Sheng, Bulk, foam, and interfacial properties of tannic acid/sodium caseinate nanocomplexes, J. Agric. Food Chem. 66 (26) (2018) 6832-6839.

[33] S.E. van Kempen, H.A. Schols, E. van der Linden, L.M. Sagis, Effect of variations in the fatty acid chain of oligofructose fatty acid esters on their foaming functionality, Food Biophys. 9 (2) (2014) 114-124.

[34] M. Matos, A. Marefati, G. Gutiérrez, M. Wahlgren, M. Rayner, Comparative emulsifying properties of octenyl succinic anhydride (OSA)-modified starch: Granular form vs dissolved state, PLoS One 11 (8) (2016) e0160140.

[35] H. Aizawa, Novel pragmatic turbidimetric data analysis method for evaluating the stability of emulsions, Int. J. Food Prop. 17 (6) (2014) 1264-1274.

[36] N.D.A.S. Neta, J.C.S. dos Santos, S. de Oliveira Sancho, S. Rodrigues, L.R.B. Gonçalves, L.R. Rodrigues, J.A. Teixeira, Enzymatic synthesis of sugar esters and their potential as surface-active stabilizers of coconut milk emulsions, Food Hydrocolloids 27 (2) (2012) 324-331.

[37] A.M. Eid, N. Elnattah, A. Elmahgoubi, M.A. Hamid, R. Hasham, A. Aziz, F.D. Ariffin, M.M. Salama, N.A. Elmarzugi, Usage of sugar ester in the preparation of avocado oil nanoemulsion, Asian J. Pharm. Clin. Res. 8 (4) (2015) 66-69.

[38] C. Chung, C.K. Koo, A. Sher, J.-T.R. Fu, P. Rousset, D.J. McClements, Modulation of caseinate-stabilized model oil-in-water emulsions with soy lecithin, Food Res. Int. 122 (2019) 361-370.

[39] K. Ren, B.P. Lamsal, Synthesis of some glucose-fatty acid esters by lipase from Candida antarctica and their emulsion functions, Food Chem. 214 (2017) 556563.

[40] Z.B. Zhu, Y. Wen, J.H. Yi, Y. Cao, F. Liu, D.J. McClements, Comparison of natural and synthetic surfactants at forming and stabilizing nanoemulsions: tea saponin, Quillaja saponin, and Tween 80, J. Colloid Interface Sci. 536 (2019) 80-87.

[41] L. Nilsson, B. Bergenståhl, Emulsification and adsorption properties of hydrophobically modified potato and barley starch, J. Agric. Food Chem. 55 (4) (2007) 1469-1474.

[42] D.J. McClements, Food Emulsions: Principles, Practice, and Techniques, second ed., CRC Press, Boca Raton, 2005.

[43] J. Rao, D.J. McClements, Food-grade microemulsions, nanoemulsions and emulsions: fabrication from sucrose monopalmitate \& lemon oil, Food Hydrocolloids 25 (6) (2011) 1413-1423.

[44] P.A. Williams, Food emulsions: principles, practice, and techniques, Intl. J. Food Sci. Tech. 36 (2) (2001) 223-224. 